\title{
Outsourcing and firm performance- a comparative study of Swiss and Greek firms
}

\section{Journal Article}

\section{Author(s):}

Arvanitis, Spyros; Loukis, Euripidis N.

Publication date:

2013-06

Permanent link:

https://doi.org/10.3929/ethz-b-000067860

Rights / license:

In Copyright - Non-Commercial Use Permitted

Originally published in:

Industrial and Corporate Change 22(3), https://doi.org/10.1093/icc/dts032 


\title{
Outsourcing and firm performance-a comparative study of Swiss and Greek firms
}

\author{
Spyros Arvanitis*,† and Euripidis N. Loukis**
}

This article aims at analyzing (i) the factors determining the firms' propensity to outsource various processes (production of intermediate products, production of final products, R\&D activities, ICT activities), and (ii) the impact of outsourcing on firms' innovation performance, as well as labor productivity. The integral investigation of the determining factors, as well as the impact of outsourcing on innovation and productivity based on the same data in a comparative setting (Switzerland versus Greece) are important new elements and contributions of this study to the existing empirical literature. It has been concluded that in both countries more innovative firms (R\&D) were stronger inclined to outsourcing activities than less innovative ones, whereas on the contrary, the educational level of employees and the labor cost showed no effect on outsourcing in both countries. Also, the intensity of ICT use and organizational aspects, especially those related to the formal structure of workplace organization, were relevant for the Swiss firms but not for the Greek firms. With respect to the impact of outsourcing on performance, it has been concluded that it tends to enhance innovation, particularly process innovation, but only weakly productivity (at least directly).

JEL classification: L24, O31.

\section{Introduction}

The considerable reduction of transport costs, but more importantly, the development and rapid diffusion of information and communication technologies (ICT) in

\footnotetext{
${ }^{\star}$ Spyros Arvanitis, ETH Zurich, KOF Swiss Economic Institute, 8092 Zurich, Switzerland. e-mail: arvanitis@kof.ethz.ch

${ }^{*}$ Euripidis N. Loukis, Department of Information and Communication Systems Engineering University of the Aegean, 83200 Karlovassi/Samos, Greece. e-mail: eloukis@aegean.gr

${ }^{\dagger}$ Main author for correspondence.
} 
the last two decades have had large economic impacts through the transformation of work processes, organizational structures and modes of inter-firm, as well as intra-firm communications. In combination with the opening of markets at both national and global levels, these technological advances led to new possibilities of trade of goods and particularly, services that allowed firms to decrease their degree of integration, thus increase their ability to operate more flexibly under the conditions of considerably more intensive international competition. Outsourcing, referring to the relocation of within-firm processes and functions to external providers either at home or abroad, has been one of these flexibility strategies (Heshmati, 2003; Olsen, 2006). Given the relative importance of outsourcing as a major firm restructuring strategy in the last 20 years, we find it reasonable to investigate both the causes of outsourcing and its consequences for firms' economic performance.

In this direction the contribution of the article is threefold: (i) analysis of the factors determining the firms' propensity to outsource various processes and functions; (ii) investigation of the impact of outsourcing on firms' innovation performance; and also (iii) on labor productivity. The integral study of the determining factors, as well as the impact of outsourcing on innovation and productivity based on the same data in a comparative setting (Switzerland versus Greece) are important new elements and contributions of this study to the existing empirical literature. A further interesting feature of this study is that it covers four important types of outsourcing and also all business sectors of the economy (manufacturing, construction and services). Further, our comparative study refers to two countries, Greece and Switzerland, which are characterized by different levels of economic development. Different levels of economic development imply different levels of technological advance also at firm-level on the average. Recent studies found that there is a link between corporate strategy and distance to (industry) technological frontier (see, e.g. Coad, 2011). Thus, it can be expected that the national environment would also exercise an influence on the type of applied corporate strategy, for example, with respect to outsourcing activities.

In this article, relocation to external providers is related to (parts of) the production process (final products and intermediate products), as well as Research and Development (R\&D) ICT activities, and is measured directly by having firms reporting whether they have externalized these particular processes and functions in the period 2000-2005. The data for 1575 Swiss firms and 254 Greek firms were collected in 2005 by means of a survey based on an identical questionnaire.

In a first step, we developed a model of the determinants of outsourcing and estimated this model for the above four different categories of outsourcing. We used a multivariate probit estimator in order to take account of the interdependence of the four outsourcing activities due to the fact that many firms reported more than one outsourcing activity. The results showed remarkable differences between the different forms of outsourcing, as well as between the two countries. Intensive use of ICT was important for the outsourcing of ICT and R\&D in Switzerland but not in Greece. 
Organizational aspects, especially those related to the formal structure of workplace organization, were relevant for the Swiss firms but not for the Greek ones. The educational level of employees showed no effect for both countries. A common trait of both countries has been that more innovative firms (R\&D) were stronger inclined to outsourcing activities than less innovative ones. Market conditions (demand, competition) were of minor importance. A further interesting result was that labor costs did not appear to be a significant factor determining the likelihood of outsourcing.

In a second step, we developed a model of innovation performance, which also included outsourcing as additional explanatory factor. The model was estimated by probit separately for product (INNOPD) and process innovation (INNOPC). The exogeneity of the sourcing variables was tested (Rivers-Vuong test) and, if necessary, an instrument variable estimation was conducted. We found positive effect of outsourcing of the production of final and intermediate products on the propensity to product innovations for both countries, and also of $\mathrm{R} \& \mathrm{D}$ outsourcing for Switzerland. Further, we found positive effects for all four outsourcing activities for Switzerland and for three of them for Greece in the case of process innovation.

In a third step, we investigated the effects of outsourcing on labor productivity by inserting the outsourcing variables in a productivity equation. Also in this case, the exogeneity of the outsourcing variables was tested. The results showed a positive effect of R\&D outsourcing in the case of Switzerland and a positive effect of the outsourcing of the production of final products in the case of Greece. Thus, the productivity effects seem to be considerably weaker than the innovation effects. Outsourcing activities tend to enhance innovation, particularly process innovation, but only weakly directly productivity; the productivity effects seem to be intermediated by new products and processes.

The structure of the article is as follows: in Section 2 the conceptual framework of the study is presented (theoretical concepts, related empirical literature, and specification of the regression models of this study). Section 3 refers to Swiss and Greek data we used for this study, whereas Section 4 to the results (concerning initially the determinants of the four examined types of outsourcing, and then their impact on innovaion and labor productivity) and Section 5 concludes.

\section{Conceptual Framework}

\subsection{Determinants of outsourcing}

\subsubsection{Basic theoretical concepts}

The theoretical discussion on a firm's decision to produce in-house or outsource through market contracts is extensive and dates back to Coase (1937) and his theory of the firm. Most of this theoretical discussion has focused on three approaches that 
are partly overlapping, partly complementary to each other: the transaction cost theory (see, e.g. Williamson, 1975), the principal-agent theory (see, e.g. Jensen and Meckling, 1976), and the property rights theory (see, e.g. Alchian and Demsetz, 1972).

According to the transaction cost theory, outsourcing can be profitable only if the expected cost advantage is higher than the sum of the costs of search efforts to find a suitable supplier, the costs of related asset-specific investments and costs of contract imperfectness. For example, if investments result in greater asset specificity as a consequence of technical advances, firms fearing expropriation of investments that are not directly controlled by the firm would avoid outsourcing.

According to agency theory, informational asymmetries with respect to employee performance between employees and employers in combination with conflicting goals and interests between these two groups of actors can lead to productivity losses. To reduce inefficiencies stemming from this source, employers can outsource part of the activities performed within the firm to external provider and control the provider performance through an outcome-based contract.

In the context of outsourcing, the property rights theory predicts that vertical integration between a supplier and a final good producer generates different cost and benefits to each of the parties (Grossman and Hart, 1986). Therefore, the incentives to integrate or outsource would depend on whether the investments of the suppliers or the producers are relatively more important for the success of their relationship.

Some of empirical studies have focused on testing these theories. For example, Acemoglu et al. (2010) found evidence consistent with the prediction of the property rights theory, namely that high technology intensity (as measured by R\&D intensity) in the final goods industry is related to more vertical integration (thus less outsourcing), whereas technology intensity in the supplier industry is associated with less integration. In a further study, Lileeva and Van Biesebroeck (2008) investigated to what extent outsourcing decisions can be explained by a simple property rights model. Their main findings were accordingly that greater specificity makes outsourcing less likely and complementarities between the investments of the buyer and the seller are also associated with less outsourcing.

However, many empirical studies use rather ad hoc theoretical frameworks, presumably due to the fact that the theoretical approaches discussed above are difficult to operationalize for empirical work (see, e.g. Osterloh, 2004).

Finally, the business and management literature emphasizes benefits and risks of outsourcing, often focusing on the importance of outsourcing of noncore activities that allows firms to concentrate on their core activities and thus increase productivity in these activities. Hamel and Prahalad (1990) first introduced the concept of core competencies in the management literature. ${ }^{1}$ This view is also in accordance with the

\footnotetext{
${ }^{1}$ See, for example, Quinn and Hilmer (1994) for a discussion on how outsourcing can enhance firms' performance on core activities.
} 
approaches in economic literature that emphasize the increasing incentives of firms to scale down ("downsizing") and specialize under the pressure of intensified international competition, as well as rapid technological change (see, e.g. Milgrom and Roberts, 1995). ${ }^{2}$

\subsubsection{An industry-equilibrium view of outsourcing}

Grossman and Helpman (2002) developed a framework for the analysis of the industrial structure, in which vertical integration or outsourcing emerges as equilibrium outcome of an industry. The main idea underlying the model is the trade-off between costs related to in-house production and contracts with external suppliers. In this sense it is related to transaction costs theory. In sum, the industry equilibrium approach of Grossman and Helpman emphasizes the relevance of two variables (not explicitly linked to the specific transaction) that are useful for empirical analysis: the number of suppliers and the degree of competition in the producing industry. However, although the number of suppliers positively affects the probability of outsourcing, the effect of more intensive competition on final goods market is not straightforward. It depends on the balance between cost advantages and diseconomies of scope for specialized and integrated firms (see the discussion in Merino and Rodriguez Rodriguez, 2007).

\subsubsection{A firm-characteristics view of outsourcing}

The role of labor costs, demand fluctuations, export propensity, and firm size: according to Abraham and Taylor (1996), a firm's decision to contract out may be influenced by costs (e.g. when suppliers pay lower wages than producers), the volatility of a firm's output demand that determines the work load of the regular workforce, thus causing high costs when the volatility is high, so that a producing firm would prefer to transfer to suppliers, and the availability of specialized skills by the external supplier that are scarce in the producing firm itself. At least two hypotheses for empirical work can be gained from this approach: (i) firms with relatively high labor costs are stronger inclined to outsource activities than firms with relatively lower labor costs; (ii) when a firm is confronted with strong fluctuating demand the incentives for outsourcing of production are higher than when it is confronted with smoothly fluctuating demand.

Görg et al. (2008) argue that exporters have a potential advantage vis-à-vis nonexporters in accessing extensive knowledge about where to procure low-cost inputs in the world market, which is an important precondition for outsourcing. This is in line with the model of Grossman and Helpman (2002), which emphasizes the importance of search costs for international sourcing.

\footnotetext{
${ }^{2}$ See Osterloh (2004: 69-111) for a survey of the literature on the motives and risks of outsourcing.
} 
The role of firm size is a rather controversial issue in literature. The management literature on core competency would suggest a negative relation between firm size and outsourcing. Small firms have strong incentives to concentrate their limited resources to core activities, thus to outsource noncore activities (see, e.g. Abraham and Taylor, 1996). In favor of a positive relation can be argued that subcontracting allows large firms to reduce costs by enhancing flexibility of production (see, e.g. Kimura, 2002). Merino and Rodriguez Rodriguez (2007) argue that firm size has a direct influence on a firm's decision to outsource. If economies of scale are relevant either in the production of some components and other intermediate inputs or in the provision of R\&D inputs we would expect small firms to be more strongly inclined to outsource such services than larger ones. In contrast, larger firms would have comparative advantages vis-à-vis smaller firms for in-house activities. However, one has to assume that beyond a certain threshold some kind of diseconomies of scale may emerge due to increasing governance problems. As a consequence, the authors postulate an inversed-U relationship between firm size and outsourcing. We postulate a positive relationship between outsourcing and firm size as the starting point of our empirical investigation (see Section 2.1.5).

The role of technology, innovation, human capital, and workplace organization: the existing literature provides controversial arguments also with respect to the influence of $\mathrm{R} \& \mathrm{D}$ on outsourcing. A more conventional view argues that $\mathrm{R} \& \mathrm{D}$-intensive industries (or firms) tend to be vertically integrated in order to compensate the high sunk costs related to $R \& D$ investment. An additional argument on the same direction is that industries (or firms) with innovative products often face appropriability problems, which they tend to solve through vertical integration (see, e.g. Teece, 1986). The idea is that technological change might deter firms from outsourcing production of a product or component, for which competitors could more easily copy an innovation (see, e.g. Williamson, 1985). Thus, there is some kind of trade-off between the incentives of saving costs and the disincentives due to the risk of copying. ${ }^{3}$

The contrary argument of a positive relationship between R\&D intensity and outsourcing is found in Bartel et al. (2009). These authors present a dynamic model, in which the probability of outsourcing production is increasing in the firm's expectation of technological change. This model abstracts from other considerations such as transaction costs or asset specificity. The main idea is that as the pace of technological change in production techniques increases, a firm has less time to amortize the sunk costs related to the adoption of new technologies. This makes producing in-house with the newest technologies relatively more expensive than

\footnotetext{
${ }^{3}$ The relationship between innovation and outsourcing can be further complicated if technological progress acts to reduce the cost asymmetries between suppliers and producers. Lewis and Sappington (1991) present a model, in which the technology-driven reduction of cost asymmetries leads to a decrease of suppliers' cost advantage, thereby making outsourcing less likely.
} 
outsourcing. A further result of this model is that larger firms facing higher adjustment costs from outsourcing, for example, due to lack of high-qualified personnel also show a higher probability of producing in-house. In accordance to this approach, we postulate a positive relationship between outsourcing and R\&D.

Particularly with respect to ICT, the rapid decline of the price of ICT and the increase of its use potential in the last years has meant that transactions that previously had to be conducted face-to-face within the firm can now be effectively conducted outside the firm. ICT reduces the external transaction and coordination costs, thus making it feasible for firms to outsource activities, which was previously prohibitively expensive to do (Abramovsky and Griffith, 2006, 2009). For example, outsourcing becomes more accessible because outside suppliers could be selected and their work coordinated by computer-based systems (Malone et al., 1987).

In a similar sense as for ICT, there are some particular organizational characteristics that also work in favor of outsourcing through the reduction of transaction and coordination costs inside the firm: (i) the flexible and less formal form of the overall firm organization as measured, for example, by the number of management levels, the flexibility of workplace organization, as indicated, for example, by the use of team-work, job-sharing, etc., and (ii) the degree of decentralization of decision-making competency inside the firm (see the literature of functional flexibility of labor, e.g. Milgrom and Roberts, 1990, Lindbeck and Snower, 2000; Kalleberg, 2001).

Further, we would expect that human capital endowment, a third important factor that is often complementary to the intensive use of ICT and flexible forms of workplace organization (see, e.g. Bresnahan et al., 2002), would influence the tendency to outsourcing in the same direction as technology or organization. The rationale is that firms employing highly qualified workers in their core activities that are paid efficiency wages can save costs through the outsourcing of peripheral activities, for which wages above efficiency wages are paid (see Gusmano et al., 2010).

There is a rather loose connection between the different literature branches but they can well serve as a conceptual guide for the specification of our model.

\subsubsection{Related empirical literature}

A series of empirical studies have been dealing recently with the factors determining the outsourcing decisions of firms in several countries. Most of them are based on firm data, whereas a few studies use industry data. There are two main groups of studies with respect to the specification of the outsourcing variables. A first larger group of papers uses binary information based on firms' reports of overall outsourcing activities and/or different types of outsourcing. A second smaller group of investigations is based on quantitative measures of intermediate material or service inputs. We could find only two studies combining both kinds of measurement (Hempell and Zwick, 2008; Bartel et al., 2009). 
To the first group of studies belong all six studies reviewed here that are based on Spanish firms data in the nineties. Merino and Rodriguez (2007) investigated based on data from about 1400 firms in 1998, twelve different categories of services outsourcing (from legal advising to advertising, software development, and software installation). These last two categories correspond to the ICT outsourcing variable used in this study and are the only type of outsourcing that is common to this study and our work. Therefore, we concentrate on the results referring to these two variables, particularly to this part of determinants that are similar to those used in this study. These are the average labor costs (negative effect for software development, no effect for software installation) and an inversed-U-effect for firm size that unifies existing divergent theoretical expectations (see the discussion in Section 2.1.3 above). Most of the other variables in this study refer to spatial factors that were not considered in our study.

The study of Diaz-Mora and Triguero (2007) based also on Spanish firms data for the period 1992-2002 used a model specification that comes near to ours. They found a positive effect on the likelihood of an (overall) outsourcing decision for the average wage, the export propensity, an indicator for market competition, and three different innovation variables, but no effect for firm size and firm age. Contrary to these results, Holl (2008) found for about 3200 Spanish firms in the period 19901999 positive effects on the likelihood of production subcontracting decisions for firm size and firm age, in addition also positive effects for the average wage and expected demand. In a further study based on the same (or a similar) data set and using the likelihood of (overall) outsourcing as dependent variable Bartel et al. (2008) could confirm-at least for one of their econometric specifications(partly) the positive effect of firm size, as well as the positive effects for firm age, expanding market demand, export propensity, $R \& D$ activities, and IT use found in some other studies. The same authors used in a further paper both kinds of outsourcing indicators (binary variable and quantitative intermediate input variable) in an investigation concentrating on the role of technology and innovation (Bartel et al., 2009). They found significant positive effects for R\&D and product innovation for both kinds of outsourcing indicators. This is an interesting result for an issue that is controversially discussed in theoretical literature (see also the discussion in Mol, 2005; see also Naghavi and Ottaviano, 2010). Negative effects of R\&D intensity on outsourcing were found, for example, in Mol (2005) for a sample of Dutch industries and in Tomiura (2008) for Japanese. To round up, a study for about 90 Spanish industries in the period 1991-2002 found a positive effect for unit labor costs and high skills but no effect for export propensity (Diaz-Mora, 2008).

To this first group of studies belong also two Italian studies that are based on firm data from Emilia Romana and the Lombardy, respectively. Mazzanti et al. (2009) used a small sample of 166 firms for their study in 1998-2001, but they disposed of an extensive vector of explanatory variables. They found positive effects for firm age and product innovation, no effect for the (relative) wage, negative effects for firm 
size, and for two organizational variables, one for organizational hierarchy a variable similar to our ORG1; Table 1) and one for organizational innovation. Gusmano et al. (2010) investigated a sample of 1200 firms in 2005 and found a positive effect for $\mathrm{R} \& \mathrm{D}$ and human capital and no significant effects for a firm being exporter and for firm size.

Finally, in a study for about 1300 UK firms in Gooroochurn and Hanley (2007) could find the following effects on the likelihood of innovation outsourcing: no effect for firm size, negative effect for R\&D intensity for process innovation and no effect for product innovation, negative effect for human capital in the case of process innovation outsourcing and no effect for product innovation outsourcing, and no effect for market concentration. The most interesting result of this study is the negative effects of variables measuring the importance of property rights.

To the second group of studies using the value of intermediate inputs divided by some overall cost measure as an outsourcing indicator belong two UK studies, one study based on Irish firms data and one based on German firms data. Girma and Görz (2004) used the cost of industry services as share of total labor costs as dependent variable in a study for about 4500 UK manufacturing firms in the period 1980-1992. The most important determinants of outsourcing according to this study are firm size (positive effect) and the average wage (also positive effects for the separately measured average wage for skilled and unskilled workers, the unskilled workers average wage showing a much lower elasticity than that of the skilled workers). A further study based on about 25,000 UK firms in 2001/2002 using the value of imported services divided by the total expenditure of purchased services as outsourcing variable found no effect for firm age and a positive effect for ICT (Abramovsky and Griffith, 2006).

Debaere et al. (2010) found in a study of 538 Irish firms in 2004, a positive effect for firm size and a positive effect for a firm being an exporter. As outsourcing variables used the authors of this study the ratio of material and service inputs over sales distinguishing imported and domestically procured materials and services.

Finally, in a study based on about 4500 German firms in 2002 and 2004, Hempell and Zwick (2008) investigated both kinds of outsourcing variables and found for both kinds positive effects for ICT use and export and a negative effect of human capital only for the share of intermediate inputs but not for the binary variable for outsourcing of business activities.

On the whole, the majority of the reviewed rather heterogeneous studies in terms of sampling and model specification show only a few common results, namely positive effects for R\&D, ICT, firm size, and export.

\subsubsection{Resulting hypotheses}

Based on the theoretical literature and the available empirical evidence, we formulate the following hypotheses for the empirical part of the study with respect to the 
Table 1 Definition of the variables

Variables Definition/measurement

OUTS IP

OUTS_FP

OUTS_R\&D

OUTS_IT

INNOPD

INNOPC

$\mathrm{LnQ} / \mathrm{L}$

ICT

INTERNET

INTRANET

ORG1

TWORK

JROT

LEVEL

ORG2

COMP_OVERALL

COMP_WORKPACE

COMP_WORKSEQ

COMP_WORKASSIGN
Outsourcing of the production of intermediate products (yes/no) 2000-2005

Outsourcing of the production of final products (yes/no) 2000-2005

Outsourcing of $R \& D$ activities (yes/no) 2000-2005

Outsourcing of IT activities (yes/no) 2000-2005

Introduction of product innovations 2003-2005

Introduction of process innovations 2003-2005

Natural logarithm of value added per employee 2004

Sum of the standardized values of the two variables INTERNET and INTRANET Six-level ordinate variable for the intensity of Internet use: share of employees using Internet in daily work: 0: 0\%; 1: 1\%-20\%; 2: 21\%-40\%; 3: 41\%-60\%; 4: $61 \%-80 \%$; 5: $81 \%-100 \%$

Six-level ordinate variable for the intensity of Intranet use: share of employees using intranet in daily work: 0 : $0 \% ; 1: 1 \%-20 \% ; 2: 21 \%-40 \% ; 3: 41 \%-60 \%$; 4: $61 \%-80 \%$; 5: $81 \%-100 \%$

Sum of the stardardized values of the three variables TWORK, JROT, and LEVEL Ordinate variable measuring how widespread is team-work inside a firm on a 5-point Likert scale (1: "very weakly widespread"; 5: "very strongly widespread"); team work: project groups, quality circles, semi-autonomous teams, etc.

Ordinate variable measuring how widespread is job rotation inside a firm on a 5-point Likert scale (1: "very weakly widespread"; 5: "very strongly widespread"); team work: project groups, quality circles, semi-autonomous teams, etc.

Three-level ordinate variable for the change of the number of managerial levels in the period 2000-2005: 1: increase; 2: no change; 3: decrease

Sum of the standardized values of the eight variables COMP_OVERALL, COMP WORKPACE, COMP WORKSEQ, COMP WORKASSIGN, CONP_WORKWAY, COMP_PRODUCTION, COMP_CUSTOMER_CONTACT, and COMP_CUSTOMER

Three-level ordinate variable measuring the change of the distribution of decision competences between managers and employees inside a firm in the period 2000-2005: 1: shift toward managers; 2: no shift; 3: shift toward employees

Ordinate variable measuring the distribution of decision competences to determine work pace (1: "primarily managers"; 5: "primarily employees")

Ordinate variable measuring the distribution of decision competences to determine the sequence of the tasks to be performed (1: "primarily managers"; 5: "primarily employees")

Ordinate variable measuring the distribution of decision competences to assign tasks to the employees (1: "primarily managers"; 5: "primarily employees") 
Table 1 Continued

\begin{tabular}{|c|c|}
\hline Variables & Definition/measurement \\
\hline COMP_WORKWAY & $\begin{array}{l}\text { Ordinate variable measuring the distribution of decision competences to de- } \\
\text { termine the way of performing tasks (1: "primarily managers"; } 5 \text { : "primarily } \\
\text { employees") }\end{array}$ \\
\hline COMP_PRODUCTION & $\begin{array}{l}\text { Ordinate variable measuring the distribution of decision competences to solve } \\
\text { emerging production problems (1: "primarily managers"; } 5 \text { : "primarily } \\
\text { employees") }\end{array}$ \\
\hline $\begin{array}{l}\text { COMP_CUSTOMER- } \\
\text { CONTACT }\end{array}$ & $\begin{array}{l}\text { Ordinate variable measuring the distribution of decision competences to } \\
\text { contact customers (1: "primarily managers"; 5: "primarily employees") }\end{array}$ \\
\hline COMP_CUSTOMER & $\begin{array}{l}\text { Ordinate variable measuring the distribution of decision competences to solve } \\
\text { emerging problems with customers (1: "primarily managers"; } 5 \text { : "primarily } \\
\text { employees") }\end{array}$ \\
\hline HQUAL & Share of employees with education at the tertiary level 2004 \\
\hline$R \& D$ & R\&D (yes/no) \\
\hline EXPORT & Exports (yes/no) 2004 \\
\hline LnLCOST/L & Natural logarithm of labor costs per employee 2004 \\
\hline D_INCREASE & $\begin{array}{l}\text { Dummy variable for firms reporting strong increase of demand (values } 4 \text { or } 5 \text { on } \\
\text { a } 5 \text {-point Likert scale (1: "very weak"; 5: "very strong") }\end{array}$ \\
\hline D_DECREASE & $\begin{array}{l}\text { Dummy variable for firms reporting strong decrease of demand (values } 1 \text { or } 2 \\
\text { on a } 5 \text {-point Likert scale (1: "very weak"; 5: "very strong") }\end{array}$ \\
\hline IPC & $\begin{array}{l}\text { Ordinate variable measuring the intensity of price competition at a firm's main } \\
\text { market on a 5-point Likert scale (1: "very weak"; 5: "very strong") }\end{array}$ \\
\hline INPC & $\begin{array}{l}\text { Ordinate variable measuring the intensity of nonprice competition (competition } \\
\text { with respect to quality, customer services, etc.) at a firm's main market on a } \\
\text { 5-point Likert scale (1: "very weak"; 5: "very strong") }\end{array}$ \\
\hline $\mathrm{LnC/L}$ & Natural logarithm of gross investment per employee 2004 \\
\hline LnHQUAL & $\begin{array}{l}\text { Natural logarithm of share of employees with education at the tertiary level } \\
2004\end{array}$ \\
\hline LnASSET/L & Natural logarithm of book value of physical capital per employee 2004 \\
\hline $\operatorname{LnR\& D/L}$ & Natural logarithm of R\&D expenditures per employee 2004 \\
\hline \multicolumn{2}{|l|}{ Firm size } \\
\hline Medium-sized firms & 50-249 employees (dummy variable) \\
\hline Large firms & 250 employees and more (dummy variable) \\
\hline \multicolumn{2}{|l|}{ Control variables } \\
\hline AGE & Firm age (foundation year minus 2005) \\
\hline High-tech industry & $\begin{array}{l}\text { Dummy variable for chemicals, plastics, machinery, electrical machinery, } \\
\text { vehicles, electronics/instruments }\end{array}$ \\
\hline Low-tech industry & Dummy variable for all other manufacturing industries \\
\hline Modern services & Dummy variable for banking/insurance, business services \\
\hline Traditional services & Dummy variable for all other service industries \\
\hline Manufacturing/services & Dummy variable for manufacturing/services (reference sector: construction) \\
\hline
\end{tabular}

Note: When nothing else is specifically mentioned, the variables refer to the period 2003-2005. 
determinants of the propensity to outsource part of firm functions and activities. In particular, we hypothesize that the likelihood that a firm is engaged in outsourcing activities is positively correlated with:

- the intensity of use of ICT.

- the intensity of use of human capital.

- the existence of $\mathrm{R} \& \mathrm{D}$ activities of the firm.

- the flexibility of the overall firm organization.

- the degree of decentralization of decision-making competency inside the firm.

- the existence of export activities.

- the average labor costs.

- high volatility of demand on the product market.

- the firm size.

It is not a priori obvious what effects should be expected for the impact of competition on the propensity of outsourcing. Thus, this issue can be resolved by the empirical investigation.

\subsubsection{Specification of the outsourcing equations}

In a first step, we specified based on the abovementioned existing theoretical and empirical literature an equation for the explanation of outsourcing at firm level. This contained variables for the use of ICT (variable ICT), the use of certain forms of workplace organization (e.g. job-rotation, team-work; variable ORG1), the degree of decentralization of decision-making (variable ORG2), the existence of $R \& D$ activities (variable $R \& D$ ), the educational level of the employees (HQUAL), the existence of export activities (EXPORT), the level of labor costs per employees $(\operatorname{lnLCOST} / \mathrm{L})$, the demand perspectives (D_INCREASE; D_DECREASE), and firm size. Further, controls for sector affiliation, firm age and the competition conditions [variables for the intensity of price competition (IPC) and nonprice competition (INPC)] were included in the outsourcing equation (Table 1 for the definition of the variables). A formal expression of the model in reduced form is as follows:

Outsourcing equation:

$$
\begin{aligned}
& \text { [OUTS_FP } \left.\left.; \text {; OUTS_IP } P_{i} ; \text { OUTS_R\&D } D_{i} ; \text { OUTS_IT } T_{i}\right)\right]=\alpha_{0}+\alpha_{1} I C T_{i} \\
& +\alpha_{2} \mathrm{OR}_{1} \mathrm{1}_{i}+\alpha_{3} \mathrm{OR}_{1} 2_{i}+\alpha_{4} \mathrm{HQUAL}_{i}+\alpha_{5} R \& D_{i}+\alpha_{6} \mathrm{EXPORT}_{i} \\
& +\alpha_{7} A_{G E_{i}}+\alpha_{8} \ln (\text { LCOST } / L)_{i}+\alpha_{9} D_{-} \text {INCREASE }_{i}+\alpha_{10} D_{-} \text {DECREASE }_{i} \\
& +\alpha_{11} I P C_{i}+\alpha_{12} I N P C_{i}+\text { FSIZE }_{i}+\text { sector dumies }+u_{i}
\end{aligned}
$$

We estimated this model for the following four categories of outsourcing: production of final products (OUTS_FP); production of intermediate products (OUTS_IP); R\&D (OUTS_R\&D); and IT (OUTS_IT). 


\subsection{Outsourcing and innovation}

\subsubsection{Theoretical notions}

We conceptualize innovation output as a function of a firm's endowment with physical capital and human capital, of demand conditions and of the intensity of competition in its specific market environment (see Dosi, 1988; Teece et al., 1997):

$$
\text { INNOV }_{i}=\alpha_{0}+\alpha_{1} C / L_{i}+\alpha_{2} \text { HC }_{i}+\alpha_{3} \text { DEMAND }_{i}+\alpha_{4} \text { COMPETITION }_{i}
$$

Where C/L is physical capital per employee, HC human capital, DEMAND the demand perspectives and COMPETITION some measure of the intensity of market competition (for firm i). Outsourcing is inserted in the innovation equation (1) as an additional factor on the right-hand side of the equation:

$$
\begin{aligned}
\text { INNOV }_{i}= & \alpha_{0}+\alpha_{1} C / L_{i}+\alpha_{2} \text { HC }_{i}+\alpha_{3} \text { DEMAND }_{i} \\
& +\alpha_{4} \text { COMPETITION }_{i}+\text { OUTS }_{i}
\end{aligned}
$$

(Where OUTS $\mathrm{i}$ is a measure of outsourcing of some activity or function).

Not all theoretical predictions about the consequences of outsourcing for innovation performance show in the same direction. Positive effects are expected, first, through an indirect "profit channel" (Görg and Hanley, 2009): outsourcing would lead to cost savings and consequently additional profits that could be re-invested in R\&D. Second, innovation performance could be enhanced also directly because outsourcing allows the restructuring of the firm toward more skill-intensive, thus more innovative activities. On the other hand, the arguments for a positive innovation effect can be opposed by considerations that the development of complex products calls for stronger vertical integration in order to optimally use specific skills that are needed for the production of such products (Novak and Eppinger, 2001).

\subsubsection{Related empirical literature}

The relation between outsourcing and innovation performance is empirically rather under-researched. Hempell and Zwick (2008), based on data from 860 German firms in the years 2002 and 2004, found that outsourcing is not associated with the likelihood of product innovations. However, outsourcing appears to lead to process innovation, that is, firms seem to optimize internal organizational structures and processes after outsourcing. Görg and Hanley (2009) investigated the effects of various categories of outsourcing on R\&D intensity ( $\& \& D$ expenditure/sales) for about 1600 Irish firms in 2002-2004. They found positive effects for domestic and international services outsourcing, partly also for domestic and international material outsourcing, whereas the effects of services outsourcing were larger than those of material outsourcing.

For this study, we postulate the following hypothesis: Outsourcing activities exercise a positive effect on firms' innovation performance. 


\subsubsection{Specification of the innovation equation}

In a second step, based on the abovementioned theoretical and empirical work, we formulated an innovation equation that contained as right-hand variables the outsourcing variables (Table 1 for the definition of the variables). Further, we distinguished between product and process innovation. A formal expression of the model is as follows:

Product innovation:

$$
\begin{aligned}
& I_{N N O P D}=\beta_{0}+\beta_{1} \ln C / L_{i}+\beta_{2} \ln (H Q U A L)_{i}+\beta_{3} D_{-} I N C R E A S E_{i} \\
& +\beta_{4} D_{-} D E C R E A S E_{i}+\beta_{5} I P C_{i}+\beta_{6} I_{N P C}+\beta_{7} \text { EXPORT }_{i} \\
& +\beta_{8}\left[\text { OUTS_FP } i \text {; OUTS_IP } i \text {; OUTS_R\&D } i \text {; OUTS_IT } T_{i}\right] \\
& + \text { controls (firm size; sector })+u_{i}
\end{aligned}
$$

Process innovation:

$$
\begin{aligned}
\text { INNOPC }_{i}= & \beta_{0}+\beta_{1} \ln C / L_{i}+\beta_{2} \ln (H Q U A L)_{i}+\beta_{3} D_{-} I N C R E A S E_{i} \\
& +\beta_{4} D_{-} D E C R E A S E_{i}+\beta_{5} I P C_{i}+\beta_{6} I N P C_{i}+\beta_{7} E_{X P O R T_{i}} \\
& +\beta_{8}\left[\text { OUTS_FP } i \text { OUTS_IP } ; \text { OUTS_R\&D } D_{i} ; \text { OUTS_IT } T_{i}\right] \\
& + \text { controls }(\text { firm size } ; \text { sector })+u_{i}
\end{aligned}
$$

[The outsourcing variables are inserted alternatively in the equations (3a) and (3b) in order to avoid multicollinearity among the outsourcing variables].

\subsection{Outsourcing and productivity}

\subsubsection{Theoretical concepts}

The impact of outsourcing on productivity is usually investigated in the production function framework. The standard approach is based on a Cobb-Douglas production function of the following form:

$$
Q_{i}=A_{i} C_{i}^{\alpha} L_{i}^{\beta}
$$

where $Q_{i}$ is value added, $A_{i}$ is the technology factor (or some other factor that serves as shift parameter), $C_{i}$ is physical capital, and $L_{i}$ is labour, whereas $\alpha+\beta=1$ (for firm i).

By taking natural logarithms and subtracting 1 (logarithm of L) from both sides of equation (4) we obtain the following expression for average labor productivity:

$$
q-l=a_{i}+\beta\left(c_{i}-l_{i}\right)
$$

where $q_{i}, a_{i}, c_{i}$, and $l_{i}$ are the natural logarithms of $Q_{i}, A_{i}, C_{i}$, and $L_{i}$, respectively.

Outsourcing has an effect on productivity through the factor $A_{i}$ of the production function. This means that outsourcing may exercise an influence on the production 
function by shifting the intercept of the log-linear production function (Olsen, 2006: 9ff.; Amiti and Wei, 2006: 5):

$$
q-l=a^{\prime}+\beta\left(c_{i}-l_{i}\right)+\gamma \text { OUTS }_{i}
$$

(where $\mathrm{OUTS}_{i}$ is a measure of outsourcing).

In our specification, we use an augmented production function that takes also human capital as additional production factor into account.

The theoretically expected effect of outsourcing on productivity is quite straightforward. Firms have an incentive to outsource if the costs of producing material and/or service inputs in-house are higher than outsourcing them. The cost differences may involve not only production costs in the narrow sense but also transaction costs. Production costs differences may refer to labor costs, scale economies, and special skills or expertise (see, e.g. Abraham and Taylor, 1996). When firms decide to outsource materials or services they relocate the less efficient parts of their production process, so average productivity increases. A further source of productivity gains may come from restructuring that becomes feasible through outsourcing. Transaction costs may be associated with negotiating and enforcing contracts or searching for appropriate external suppliers (see, e.g. Grossman and Helpman, 2002).

\subsubsection{Related empirical literature}

The relation between outsourcing and economic performance, mostly average labor productivity, of the outsourcing firm has been investigated in some recent empirical studies based on firm data. Using the total cost share of material inputs and the total cost share of service inputs as outsourcing indicators Görzig and Stephan (2002) found for a large sample of German firms in the period 1992-2000 a positive impact of material inputs but no effect of service inputs on the return per employee and a positive effect of service inputs on return on sales only in the within-estimations. Ohnemus (2007) investigated the impact of IT outsourcing on labor productivity for about 1400 German firms in 2004 and found a significant positive effect. In a further study the same author found also a positive effect for business process outsourcing on labor productivity for 698 German firms in the period 2000-2007 (Ohnemus, 2009). In both studies outsourcing was measured by a (yes/no)-binary variable.

Götz and Hanley (2004) in a study for 368 Irish electronics firms in the period 1990-1995 found that plants that are substantially larger than the mean employment size benefit in terms of profitability from outsourcing materials and service inputs, whereas this does not seem to be the case for small plants. However, the results for outsourcing of services are not as clear-cut. McCann (2009) investigated the influence of the share of imported and domestic material inputs, as well as the share of service inputs on labor productivity separately for exporters, nonexporters and foreign-owned firms. The study was based on a sample of 1564 Irish firms in 1991-2005. The author found a positive effect of imported material inputs on the productivity of exporters, also a positive effect of domestic material inputs for 
nonexporters and a negative effect of service inputs on the productivity of nonexporters. No effect could be found for the entire sample. In a third study also based on Irish firm data (1099 firms; 1990-1998) Görg et al. (2008) found a positive effect of the share of imported services on the total factor productivity of exporters but not of nonexporters. The results of the two last studies demonstrate that experience in foreign markets is a necessary condition for positive economic effects of outsourcing to foreign supplies, at least for Irish firms. Finally, Görg and Hanley (2009) found for a sample of about 1600 Irish firms in 2002-2004 positive effects on profitability for international and domestic services outsourcing, as well as for domestic material outsourcing but, rather surprisingly, not for international material outsourcing.

Based on the data for about 4400 UK firms in 1980-1992, Girma and Görg (2004) found a significant positive effect of material input intensity on labor productivity for firms in all three sectors (chemicals, electronics, engineering) they investigated. In a further study for a large sample of 70,044 British establishments in 2000-2003, Abramovsky and Griffith (2009) found positive effects for expenditure shares of purchased materials and services on labor productivity, where the effect of material inputs is larger than that for service inputs.

In a study based on data for about 750 US firms in 1992-2000 Amiti and Wei (2006) found clearly positive effects of both imported material and service inputs on both labor productivity and total factor productivity. In the case of labor productivity, the effect of services input is larger than that of material inputs. Finally, in a study for 213 Spanish firms in 2006/2007, Bustinza-Sanchez et al. (2010) found a positive effect of outsourcing on a composite measure of economic performance that was constructed based on factor analysis of several single measures of firm performance.

In sum, the empirical results appear to be mixed, with a tendency to positive productivity effects dependent on specific characteristics of the involved firms.

We formulate the following hypothesis: Outsourcing activities exercise a positive effect on firms' average labor productivity.

\subsubsection{Specification of the productivity equation}

In a third step, we investigated the effects of outsourcing on labor productivity by inserting the outsourcing variables in a productivity equation as specified in equation (6):

Labor productivity:

$$
\begin{aligned}
\ln (Q / L)_{i}= & \gamma_{0}+\gamma_{1} \ln (C / L)_{i}+\gamma_{2} \ln (R \& D / L)_{i} \\
& +\gamma_{3}\left[\text { OUTS_FP } P_{i} ; \text { OUTS_IP } ; \text { OUTS_R\&D } D_{i} ; \text { OUTS_IT } T_{i}\right] \\
& + \text { controls }(\text { firm size } ; \text { sector })+u_{i}
\end{aligned}
$$


(The outsourcing variables are inserted alternatively in the equation (6); R\&D/L: R\&D expenditures per employee; Table 1 for the definition of the variables).

\section{Data}

Both Swiss and Greek surveys were conducted in autumn 2005. The reference period for the qualitative data is the period 2003-2005 unless otherwise mentioned (Table 2). The reference year for the quantitative variable is 2004. The reference period for the outsourcing variables is the period 2000-2005. Differences with respect to the composition of the data by industry in Table A1 appear to reflect the structural difference between the two countries. For example, the share of textile and clothing firms, hotels, and catering firms is significantly higher in Greece. On the other hand, metal working, machinery, electrical machinery, and electronics/instruments are much stronger represented in Switzerland [Tables with descriptive statistics and correlation tables of the used variables are not included in the article in order to keep it shorter, but they can be found in Arvanitis and Loukis (2011)].

\subsection{Swiss data}

The data used in the Swiss part of this study were collected in the course of a postal survey among Swiss enterprises using a questionnaire which included questions on the incidence and within-firm diffusion of several ICT technologies (e-mail, Internet, intranet, extranet) and new organizational practices (team-work, job rotation, employees' involvement), employees' vocational education and job-related training, and also on basic economic data for 2004 (sales, value of intermediate inputs, investment expenditure, number of employees, etc.). ${ }^{4}$ The survey was based on a disproportionately stratified (with respect to firm size) random sample of firms with at least 20 employees covering all relevant industries of the business sector, as well as firm size classes (on the whole 29 industries, and within each industry three industry-specific firm size classes with full coverage of the upper class of large firms). ${ }^{5}$ Answers were received from 1803 firms, that is, $38.7 \%$ of the firms in the underlying sample. The response rates do not vary much across industries and size classes with a few exceptions (over-representation of paper and energy industry, under-representation of

\footnotetext{
${ }^{4}$ The questionnaire was based on a considerable extent on similar questionnaires used in earlier surveys (see EPOC, 1997; Francois et al. 1999, Vickery and Wurzburg, 1998; Canada Statistics, 1999). Versions of the questionnaire in German, French, and Italian are available in www.kof. ethz.ch.

${ }^{5}$ Table A1 contains only 26 industries; the Swiss sample has "watches", "telecommunication", and "computer services" as separate industries that were put together with "electronics/instruments", "transport", and "other business services", respectively to make the industry classification comparable with that of the Greek data.
} 
Table 2 Various types of outsourcing

\begin{tabular}{lcc}
\hline Outsourcing of & $\begin{array}{l}\text { Switzerland } \\
N(\%)\end{array}$ & $\begin{array}{l}\text { Greece } \\
N(\%)\end{array}$ \\
\hline Production of final products & $231(12.8)$ & $34(12.5)$ \\
Production of intermediate products & $197(10.9)$ & $31(11.4)$ \\
Research and development (R\&D) & $77(4.3)$ & $16(5.9)$ \\
Information technology & $271(15.0)$ & $61(22.5)$
\end{tabular}

Note: Percentage of all firms (Switzerland: $N=1803$; Greece: $N=271$ )

hotels, catering, and retail trade). In Table A1 of the appendix in column 2, we can see the structure of the data set we used for the Swiss part of this study by industry and firm size class. The nonresponse analysis (based on a follow-up survey of a sample of the nonrespondents) did not indicate any serious selectivity bias with respect to the use of ICT and new organizational practices (team-work, job rotation). A careful examination of the data of these 1803 firms led to the exclusion of 93 cases with contradictory or nonplausible answers. However, missing values for certain variables allowed the utilization of only 1575 observations.

\subsection{Greek data}

The data we used in the Greek part of this study were collected through a postal survey among Greek enterprises based on the same questionnaire that has been used in the Swiss part of the study. This questionnaire was translated into Greek and pretested by three experts highly experienced in such surveys and questionnaires. Three samples of 300 Greek firms each were randomly selected from the database of ICAP, a major Greek business intelligence firm (which consists of approximately 135,000 Greek firms from all industries), being all structurally similar to the sample of the Swiss part of the study with respect to industries and firm size classes. Firms that definitely refused to participate in this survey were replaced by similar firms (i.e. from the same industry and size class) from the second sample, whereas in a few cases, that exhausted the firms of the second sample, we had to proceed to the third sample. Following the above procedure, which aimed to maintain the proportions of industry and size classes, we finally received responses from 281 firms; after an examination of the returned completed questionnaires, we excluded 10 cases with contradictory or nonplausible answers, and the remaining 271 valid responses were used for the analyses. In Table A1, in column 1 we can see the structure of the final data set we used for the Greek part of the by industry and firm size class. A nonresponse analysis was performed (survey of a sample of the nonrespondents), which did not indicate any serious selectivity bias with respect to the use of ICT, new 
organizational practices, vocational education, and job-related training. For these 271 firms we also retrieved from the database of ICAP some economic data for 2004 that were not collected through the questionnaire. So we finally obtained for all these Greek firms all the economic data that were collected for the firms of the above Swiss data set through the Swiss questionnaire. However, due to missing values for certain variables only 254 observations could effectively be used in the econometric estimations.

\section{Results}

\subsection{Methodological remarks}

\subsubsection{Interdependence of the outsourcing variables}

Firms in our data often reported more than one category of outsourcing for the same time period. For this reason, in a first step we took into consideration the interdependence among the outsourcing variables. According to the relevant econometric literature [e.g. see Greene's (2011) Econometric Analysis] the recommended approach for such cases is the multivariate probit estimation, which is a generalization of the probit estimator that estimates jointly several probit models that have correlated binary dependent variables. Thefore, we proceeded to the estimation of a multivariate probit model, that is a simultaneous system of four outsourcing equations for the four different types of outsourcing, instead of four separate probits. We applied the procedure implemented in STATA that is based on the so-called GHK-simulator for multivariate distributions. ${ }^{6}$

\subsubsection{Endogeneity issues}

Outsourcing equations: there is a potential endogeneity problem with respect to the determinants of outsourcing propensity due to the fact that both the dependent and the independent variables are cross-section data with only partial overlapping. We refrained from a rigorous testing of endogeneity of the numerous right-hand variables in the outsourcing equations because, it was quite questionable if such testing would be an adequate procedure given the unusual time structure of this part of the data. As a consequence, our estimates of the outsourcing equations have to be seen primarily as an extensive analysis of the correlations between the determinants (that are considered as structural characteristics that change only slowly over time) and the outsourcing variables (see Mazzanti et al., 2009: 348; Michie and Sheenan, 2005: 450

\footnotetext{
${ }^{6}$ The STATA procedure 'mprobit' estimates M-equation probit models by the method of simulated maximum likelihood. The Geweke-Hajivassiliou-Keane (GHK)-simulator is applied to evaluate the M-dimensional normal integrals in the likelihood function (for a description of the GHK-simulator see Greene 2003).
} 
for a similar argumentation). Nevertheless, some robust regularities come out, which if interpreted in view of our hypotheses presented in Section 2.1.5 could possibly indicate the direction of causal links.

Innovation and productivity equations: we found it not only necessary, but also feasible to test the possibility of endogeneity of the outsourcing variables when used as right-hand variables in the two innovation equations and the productivity equation, respectively. In both cases the outsourcing decisions are to a considerable extent predetermined (reference period 2000-2005) with respect to the performance variables (reference period for innovation variables 2003-2005, for productivity variables 2004).

We tested endogeneity by applying the procedure by Rivers and Vuong (1988). Instrument equations were estimated separately for each outsourcing variable for both innovation equations and the productivity equations for each country. The instrument choice was based on three criteria: significant correlation to the instrumented variables (the four types of outsourcing), insignificant correlation to the dependent variables (INNOPD, INNOPC, LnQ/L) and insignificant correlation to the error term of the innovation equations and the productivity equations, respectively. The residuals (predicted instrumented variables minus original variable) of the first stage instrument equations were inserted in the innovation equation as additional regressors. Bootstrapping was used in order to correct the standard errors of the estimated parameters. If the coefficient of the residuals was statistically significant (at the $10 \%$-test level), we have assumed that endogeneity is a problem and consequently based our inference on instrumented variables; also in this case, standard errors were estimated by bootstrapping. In cases in which the coefficient of the residual was not statistically significant, we have assumed exogeneity of the outsourcing variables and the estimates were based on the original variables.

On the whole, we tested 12 estimates (four different outsourcing variables for the two innovation equations and the productivity equation) for each country. In 11 out of 12 cases for the Swiss data the coefficients of the residuals (predicted instrumented variables minus original variable) were statistically insignificant at the $10 \%$ test level. Therefore, for these cases we could not find any evidence for endogeneity in our estimates for innovation and productivity. Only in the case of the outsourcing variable OUTS_EP in the INNOPC-equation was the coefficient of the residual statistical significant. In 9 out of 12 cases for the Greek data no evidence for endogeneity could be found. In three cases the residual were statistically significant and the instrumentation was necessary (OUTS_IP in both innovation equations and OUTS_EP in the productivity equations). ${ }^{7}$

\footnotetext{
${ }^{7}$ The tables with the instrument equations and the results of the endogeneity tests were not included in the article in order to keep it shorter, but they are available in Arvanitis and Loukis (2011).
} 


\subsection{Outsourcing equations}

As Table 2 shows, the four types of outsourcing that are investigated in this study are almost equally represented in both countries-with the exception of ICT outsourcing, which has been significantly more likely to take place in Greece than in Switzerland in the period 2000-2005. In both countries ICT outsourcing has been the most frequently used type of outsourcing. About 15\% of all firms in the Swiss sample have had relocation of ICT activities in that period of time, with the respective figure for the Greek sample being $22.5 \%$.

The Tables 3 and 4, respectively show the multivariate probit estimates for the four outsourcing categories for Switzerland and Greece. ${ }^{8}$ We identify three central features in our results. First, the four types of outsourcing are relatively closely inter-related (see the correlation measures $\rho 21$ to $\rho 43$ in the lower part of Tables 3 and 4, respectively). The strongest correlation in both countries is between outsourcing of intermediate and final products $(\rho 12=0.628$ for the Swiss firms; $\rho 12=0.687$ for the Greek firms). Further strong correlations are found in Switzerland between intermediate and final products and R\&D. All other links are significantly weaker. The links between the various types of outsourcing are stronger in Greece than in Switzerland (with the exception of the link between R\&D and final products). On the whole, the relatively strong positive links between the kinds of outsourcing point out to complementarities between these types of outsourcing. Firms seem to apply strategies of restructuring that are oriented at increasing efficiency in more than one bundle of activities at the same time.

Second, we find significant differences with respect to the relevance of the various factors depending on the kind of outsourcing that is undertaken by a firm. Third, our model seems to fit better to the Swiss than the Greek data, as we found, based on separate probit estimates for each outsourcing type not presented here. The low number of Greek observations could explain only partially this difference.

More concretely, being involved in R\&D activities is positively correlated with the likelihood of outsourcing the production of both intermediate and final products, as well as R\&D in Switzerland and the production of intermediate products, R\&D and IT in Greece. The R\&D effect is clearly the strongest common effect. Our results seem to confirm the theoretical expectations in Bartel et al. (2009). These authors' main idea is that as the pace of technological change in production techniques increases, a firm has less time to amortize the sunk costs related to the adoption of new technologies. This makes producing in-house with the newest technologies relatively more expensive than outsourcing. As a consequence, firms try to reduce costs through the outsourcing of certain parts of production that can be purchased cheaper from external providers.

\footnotetext{
${ }^{8}$ We had to remove the dummy variable for medium-sized firms in the Greek estimates in order to achieve a convergence of the estimation procedure.
} 
Table 3 Multivariate probit estimates of outsourcing equations for Switzerland

\begin{tabular}{|c|c|c|c|c|}
\hline Explanatory variables & OUTS_FP & OUTS_IP & OUTS_R\&D & OUTS_IT \\
\hline $\mathrm{ICT}$ & $0.017(0.033)$ & $0.026(0.033)$ & $0.085^{* *}(0.043)$ & $0.076^{* * *}(0.027)$ \\
\hline ORG1 & $0.047^{* *}(0.023)$ & $0.036(0.024)$ & $0.068 * *(0.030)$ & $0.084^{* * *}(0.021)$ \\
\hline ORG2 & $0.019 *(0.010)$ & $0.006(0.010)$ & $-0.021(0.014)$ & $0.001(0.009)$ \\
\hline HQUAL & $0.005(0.003)$ & $0.005(0.003)$ & $0.001(0.004)$ & $-0.002(0.003)$ \\
\hline$R \& D$ & $0.293^{* * *}(0.010)$ & $0.206^{* *}(0.104)$ & $0.422^{* * *}(0.145)$ & $-0.016(0.092)$ \\
\hline EXPORT & $0.317^{* * *}(0.123)$ & $0.262 * * *(0.127)$ & $0.187(0.171)$ & $-0.046(0.098)$ \\
\hline AGE & $0.001(0.001)$ & $0.001(0.001)$ & $0.002(0.002)$ & $0.000(0.009)$ \\
\hline LnLCOST/L & $-0.020(0.075)$ & $0.027(0.072)$ & $-0.089(0.095)$ & $-0.047(0.060)$ \\
\hline D_INCREASE & $0.162(0.104)$ & $0.066(0.107)$ & $0.122(0.141)$ & $0.027(0.091)$ \\
\hline D_DECREASE & $0.096(0.120)$ & $0.184(0.119)$ & $0.035(0.168)$ & $-0.028(0.105)$ \\
\hline IPC & $0.148^{* * *}(0.050)$ & $0.063(0.049)$ & $0.018(0.065)$ & $0.006(0.040)$ \\
\hline INPC & $-0.001(0.047)$ & $0.030(0.048)$ & $0.029(0.062)$ & $-0.017(0.040)$ \\
\hline \multicolumn{5}{|l|}{ Firm size } \\
\hline Medium-sized firms & $0.056(0.074)$ & $0.146 *(0.078)$ & $-0.031(0.097)$ & $0.069(0.062)$ \\
\hline Large firms & $0.030(0.087)$ & $0.156^{*}(0.085)$ & $0.083(0.109)$ & $0.142^{* *}(0.072)$ \\
\hline \multicolumn{5}{|l|}{ Sector } \\
\hline High-tech manufacturing & $0.517 * *(0.208)$ & $0.364 *(0.200)$ & $0.068(0.268)$ & $-0.162(0.170)$ \\
\hline Low-tech manufacturing & $0.341 *(0.196)$ & $0.116(0.186)$ & $-0.150(0.258)$ & $-0.021(0.153)$ \\
\hline $\begin{array}{l}\text { Knowledge-intensive } \\
\text { services }\end{array}$ & $-0.474^{*}(0.251)$ & $-0.721^{* * *}(0.249)$ & $-0.614^{*}(0.327)$ & $0.043(0.179)$ \\
\hline Traditional services & $-0.302(0.218)$ & $-0.648 * * *(0.219)$ & $-0.286(0.273)$ & $-0.017(0.149)$ \\
\hline$N$ & 1575 & & & \\
\hline Wald $\chi^{2}$ & $306.6^{* * *}$ & & & \\
\hline$\rho 21$ & $0.628^{* * *}$ & & & \\
\hline$\rho 31$ & $0.449 * * *$ & & & \\
\hline$\rho 41$ & $0.248^{* * *}$ & & & \\
\hline$\rho 32$ & $0.429 * * *$ & & & \\
\hline$\rho 42$ & $0.224 * * *$ & & & \\
\hline$\rho 43$ & $0.353^{* * *}$ & & & \\
\hline \multicolumn{5}{|l|}{ LR-test of } \\
\hline \multicolumn{5}{|l|}{$\rho 21=\ldots=$} \\
\hline \multicolumn{5}{|l|}{$\rho 43=0$} \\
\hline$\chi^{2}=244.1^{* * *}$ & & & & \\
\hline
\end{tabular}

Note: Statistical significance at ${ }^{\star * \star} 1 \%,{ }^{\star *} 5 \%$, and ${ }^{\star} 10 \%$ test levels, respectively; heteroscedasticity-robust standard errors (White-procedure).

On the contrary, labor costs do not seem to be the kind of costs that firms want to reduce through outsourcing. For both countries we could not find any significant effect for the variable LnLCOST/L.

The intensive use of ICT is a further important factor related positively with the outsourcing of R\&D and ICT in Switzerland but not in Greece. The main reason for 
Table 4 Multivariate probit estimates of outsourcing equations for Greece

\begin{tabular}{|c|c|c|c|c|}
\hline Explanatory variables & OUTS_FP & OUTS_IP & OUTS_R\&D & OUTS_IT \\
\hline ICT & $0.019(0.078)$ & $-0.130(0.088)$ & $-0.132(0.112)$ & $0.023(0.064)$ \\
\hline ORG1 & $-0.028(0.063)$ & $0.041(0.062)$ & $0.009(0.086)$ & $-0.035(0.048)$ \\
\hline ORG2 & $0.005(0.025)$ & $0.012(0.025)$ & $0.054(0.035)$ & $0.009(0.021)$ \\
\hline HQUAL & $-0.006(0.007)$ & $-0.001(0.007)$ & $0.005(0.009)$ & $0.003(0.005)$ \\
\hline$R \& D$ & $-0.041(0.242)$ & $0.442 *(0.239)$ & $0.883^{* * *}(0.324)$ & $0.409 * *(0.196)$ \\
\hline EXPORT & $0.217(0.240)$ & $0.307(0.259)$ & $0.250(0.359)$ & $0.330 *(0.201)$ \\
\hline AGE & $-0.008(0.007)$ & $-0.013^{*}(0.007)$ & $-0.012(0.009)$ & $0.005(0.004)$ \\
\hline LnLCOST/L & $0.061(0.115)$ & $-0.057(0.102)$ & $-0.111(0.143)$ & $-0.060(0.079)$ \\
\hline D_INCREASE & $-0.294(0.265)$ & $-0.041(0.270)$ & $0.010(0.371)$ & $0.021(0.228)$ \\
\hline D_DECREASE & $-0.629(0.409)$ & $-0.716(0.445)$ & $-2.340(4.972))$ & $-0.432(0.332)$ \\
\hline IPC & $0.007(0.113)$ & $0.012(0.130)$ & $-0.170(0.164)$ & $0.110(0.097)$ \\
\hline INPC & $-0.162(0.105)$ & $0.024(0.112)$ & $0.135(0.175)$ & $0.139(0.087)$ \\
\hline \multicolumn{5}{|l|}{ Firm size } \\
\hline Large firms & $0.033(0.254)$ & $0.048(0.256)$ & $0.837 * *(0.333)$ & $0.043(0.203)$ \\
\hline \multicolumn{5}{|l|}{ Sector } \\
\hline Manufacturing/services & $-0.456^{*}(0.239)$ & $-0.432 *(0.245)$ & $0.977^{* *}(0.412)$ & $0.271(0.200)$ \\
\hline$N$ & 254 & & & \\
\hline Wald $\chi^{2}$ & $71.8^{*}$ & & & \\
\hline$\rho 21$ & $0.687^{* * *}$ & & & \\
\hline$\rho 31$ & 0.240 & & & \\
\hline$\rho 41$ & $0.533^{* * *}$ & & & \\
\hline$\rho 32$ & $0.574 * * *$ & & & \\
\hline$\rho 42$ & $0.537^{* * *}$ & & & \\
\hline$\rho 43$ & $0.596^{* * *}$ & & & \\
\hline \multicolumn{5}{|l|}{ LR-test of } \\
\hline \multicolumn{5}{|l|}{$\rho 21=\ldots=r$} \\
\hline \multicolumn{5}{|l|}{$\rho 43=0:$} \\
\hline$\chi^{2}=85.2^{* * *}$ & & & & \\
\hline
\end{tabular}

Note: Statistical significance at ${ }^{* *} 1 \%,{ }^{*} 5 \%$, and ${ }^{\star} 10 \%$ test levels, respectively; heteroscedasticity-robust standard errors (White-procedure).

this difference is presumably the lower effectiveness and maturity of Greek firms in using ICT in comparison with Swiss firms identified in previous studies (see Arvanitis and Loukis, 2009).

For Switzerland, both organizational variables (ORG1, ORG2) are positively correlated with the likelihood of outsourcing the production of final products, whereas ORG1 is also correlated with the likelihood of outsourcing R\&D and IT. Therefore, restructuring through outsourcing is positively linked to changes of overall organizational structure through the reduction of the number of management levels and/or changes of workplace organization (team-work, job-rotation) leading to more operational efficiency. Stronger employee participation through 
decentralization of decision-making (ORG2) does not appear to be equally important for outsourcing. Employee participation is directly contributing to productivity but is less relevant for efficiency increases through outsourcing. Not astonishingly, no such effects could be found for Greek firms, presumably for the same reasons as in the case of ICT.

Swiss exporting firms show a higher outsourcing propensity than nonexporting firms, a result that is in accordance with earlier empirical studies (see Diaz-Mora and Triguero, 2007, Bartel et al., 2008, Gusmano et al., 2010, and Debaere et al., 2010).

For both countries we could not find any effect for firm age (with the exception of a negative sign of this variable in the Greek estimates for the outsourcing of intermediate products), demand conditions, and competition pressure (with the exception of a positive correlation between outsourcing of final products and price pressure for Switzerland that could be interpreted as a hint for cost-saving outsourcing). The lack of demand effects for the period 2003-2005 could be explained by the fact that this period has been for both countries a boom period and demand development has been quite similar for most firms.

The controversy about the signs of firm size effects cannot be resolved by our results. There is a tendency for a positive relation between the dummies medium-sized and large firms (as compared with small firms) and outsourcing of intermediate products and between the dummy for large firms and the outsourcing of IT for Swiss firms. The latter effect could be observed, for example, in the bank and insurance sector, where many larger firms began to restructure the IT departments that have grown meanwhile, to rather inefficient part-organizations. For Greece the relation between firm size (large firms as compared with all other firms) is positive only in the case of R\&D outsourcing. Presumably this effect can be explained by the fact that only larger firms have $R \& D$ activities in the Greek economy, so that only for such firms is $\mathrm{R} \& \mathrm{D}$ outsourcing a strategic option.

In the Swiss economy the outsourcing of parts of production (intermediate and final products) is primarily a strategy pursued by manufacturing firms, particularly firms belonging to high-tech industry. Outsourcing of R\&D and IT is not a particular characteristic of the manufacturing sector; it takes place at the same extent in all sectors (with the exception of knowledge-intensive service industries as for $\mathrm{R} \& \mathrm{D}$ outsourcing). We find a different picture for the Greek economy. The outsourcing of production is most common in the construction sector, which is besides tourism, one of the largest and most dynamic sectors of the Greek economy. Manufacturing and service firms show a higher propensity than construction firms only with respect to the outsourcing of R\&D.

\subsection{Innovation equations}

The likelihood of product innovation is positively correlated with three kinds of outsourcing in the case of Swiss firms: outsourcing of production (of intermediate 
and final products) and $R \& D$ (Table 5). For the Greek firms we found a positive correlation of product innovation with the outsourcing only of production (intermediate and final products) (Table 6). The effects for process innovation are positive and statistically significant for all four types of outsourcing for the Swiss firms (Table 7) and for three kinds of outsourcing (no effect for R\&D outsourcing) for the Greek firms (Table 8).

We cannot distinguish whether the positive effects can be traced back to an indirect "profit channel" (Görg and Hanley, 2009) leading to cost savings and consequently additional profits that were re-invested in $\mathrm{R} \& \mathrm{D}$ or whether innovation performance could be enhanced directly because outsourcing allowed the restructuring of the firm towards more skill-intensive and more innovative activities. On the whole, our results confirm clearly the theoretical argumentation that expects a positive impact of outsourcing on innovation. Particularly the results for process innovation can be interpreted as a clear hint for cost-saving outsourcing, especially of less efficient parts of production, that allow to reinvest additionally available resources both in new products and in more efficient production techniques.

There are significant differences between the estimates for the Swiss and the Greek firms with respect to the other variables in the innovation equations. In the case of the Swiss firms the signs of the variables for capital intensity, human capital, demand development, and price and nonprice competition pressure are as expected for both kinds of innovation throughout positive and the respective coefficients statistically significant. Export is significant only in the product innovation equation. For the Greek firms only the human capital and the export variable show a positive effect for product innovation. The insignificance of so many relevant factors reflects to some extent the rather diffuse profile of innovation activities in the Greek economy.

\subsection{Productivity equations}

The results in the Tables 9 and 10, respectively show a positive effect of R\&D outsourcing in the case of Switzerland and a positive effect of the outsourcing of the production of final products in the case of Greece. The result for R\&D outsourcing is quite in accordance with the findings of earlier studies about the positive effects of $\mathrm{R} \& \mathrm{D}$ investment in foreign locations (off-shoring of $\mathrm{R} \& \mathrm{D}$ ) (see Arvanitis and Hollenstein, 2007, 2011). The positive effect of outsourcing of final products on productivity pointing out to a primarily cost-saving outsourcing strategy is in accordance with the results of recent studies about the effects of off-shoring of production to foreign locations such as Romania, Bulgaria, etc. (see Dimelis and Louri, 2002; and Barrios et al., 2004).

Thus, the productivity effects seem to be considerably weaker than the innovation effects. Outsourcing activities tend to enhance innovation, particularly process innovation, but only weakly directly productivity; the productivity effects seem to be 
Table 5 Probit estimates of the product innovation equations with outsourcing variables for Switzerland

\begin{tabular}{|c|c|c|c|c|}
\hline $\begin{array}{c}\text { Explanatory } \\
\text { variables }\end{array}$ & INNOPD & INNOPD & INNOPD & INNOPD \\
\hline $\mathrm{LnC/L}$ & $0.097 * * *(0.022)$ & $0.095^{* * *}(0.022)$ & $0.094 * * *(0.022)$ & $0.094^{* * *}(0.021)$ \\
\hline LnHQUAL & $0.110 * * *(0.037)$ & $0.116^{* * *}(0.037)$ & $0.121 * * *(0.037)$ & $0.123^{* * *}(0.036)$ \\
\hline D_INCREASE & $0.233^{* * *}(0.075)$ & $0.240 * * *(0.075)$ & $0.239 * * *(0.074)$ & $0.240 * * *(0.074)$ \\
\hline D_DECREASE & $0.182^{* * *}(0.084)$ & $0.172^{* *}(0.084)$ & $0.185^{* *}(0.084)$ & $0.186^{* *}(0.084)$ \\
\hline IPC & $0.072^{* *}(0.032)$ & $0.080 * *(0.032)$ & $0.082^{* *}(0.032)$ & $0.083^{* *}(0.032)$ \\
\hline INPC & $0.152 * * *(0.033)$ & $0.146^{* * *}(0.033)$ & $0.147^{* * *}(0.033)$ & $0.149^{* * *}(0.033)$ \\
\hline EXPORT & $0.137 *(0.077)$ & $0.144^{*}(0.077)$ & $0.152^{* *}(0.077)$ & $0.161^{* *}(0.077)$ \\
\hline OUTS_FP & $0.497^{* * *}(0.108)$ & & & \\
\hline OUTS_IP & & $0.401^{* * *}(0.118)$ & & \\
\hline OUTS_R\&D & & & $0.375^{* * *}(0.183)$ & \\
\hline OUTS_IT & & & & $0.109(0.091)$ \\
\hline \multicolumn{5}{|l|}{ Firm size } \\
\hline Medium-sized firms & $0.024(0.038)$ & $0.018(0.038)$ & $0.029(0.038)$ & $0.024(0.038)$ \\
\hline Large firms & $0.174 * * *(0.032)$ & $0.164 * * *(0.032)$ & $0.176^{* * *}(0.032)$ & $0.172 * * *(0.032)$ \\
\hline \multicolumn{5}{|l|}{ Sector } \\
\hline $\begin{array}{l}\text { High-tech } \\
\qquad \text { manufacturing }\end{array}$ & $1.147^{* * *}(0.136)$ & $1.183^{* * *}(0.136)$ & $1.213^{* * *}(0.135)$ & $1.221 * * *(0.135)$ \\
\hline $\begin{array}{l}\text { Low-tech } \\
\quad \text { manufacturing }\end{array}$ & $0.712^{* * *}(0.124)$ & $0.750 * * *(0.124)$ & $0.761^{* * *}(0.135)$ & $0.757^{* * *}(0.124)$ \\
\hline $\begin{array}{l}\text { Knowledge-intensive } \\
\text { services }\end{array}$ & $0.335^{* *}(0.138)$ & $0.353^{* * *}(0.138)$ & $0.338^{* *}(0.137)$ & $0.321^{* * *}(0.137)$ \\
\hline Traditional services & $0.320 * * *(0.121)$ & $0.342 * * *(0.121)$ & $0.327^{* * *}(0.121)$ & $0.319 * * *(0.121)$ \\
\hline$N$ & 1575 & 1575 & 1575 & 1575 \\
\hline Pseudo $R^{2}$ & 0.166 & 0.162 & 0.159 & 0.158 \\
\hline Wald $\chi^{2}$ & $353.6^{* * *}$ & $354.3^{* * *}$ & $348.2^{* * *}$ & $349.1^{* * *}$ \\
\hline
\end{tabular}

Note: Statistical significance at ${ }^{* *} 1 \%,{ }^{*} 5 \%$, and ${ }^{\star} 10 \%$ test levels, respectively; heterosceda-sticity-robust standard errors (White-procedure).

intermediated (at least for Switzerland) by R\&D investment in new products and processes.

The other variables in the productivity estimates for Switzerland show the expected positive effects (capital intensity and $R \& D$ intensity). In the estimates for the Greek firms, only the coefficient for the capital intensity variable is positive and statistically significant, whereas the coefficient of the R\&D intensity variable is positive but not significant reflecting the rather low relevance of $R \& D$ in the Greek economy (Arvanitis and Loukis, 2009). 
Table 6 Probit estimates of the product innovation equations with outsourcing variables for Greece

\begin{tabular}{|c|c|c|c|c|}
\hline Explanatory variables & INNOPD & INNOPD & INNOPD & INNOPD \\
\hline LnASSET/L & $-0.009(0.053)$ & $-0.048(0.058)$ & $-0.003(0.053)$ & $-0.002(0.053)$ \\
\hline InHQUAL & $0.195^{* *}(0.089)$ & $0.131(0.102)$ & $0.184^{* *}(0.088)$ & $0.184^{* *}(0.087)$ \\
\hline D_INCREASE & $0.005(0.216)$ & $0.055(0.260)$ & $-0.042(0.214)$ & $-0.040(0.215)$ \\
\hline D_DECREASE & $-0.188(0.316)$ & $1.798 * * *(0.543)$ & $-0.256(0.315)$ & $-0.268(0.316)$ \\
\hline IPC & $0.093(0.094)$ & $0.113(0.101)$ & $0.105(0.095)$ & $0.101(0.095)$ \\
\hline INPC & $-0.008(0.083)$ & $-0.022(0.098)$ & $-0.031(0.083)$ & $-0.027(0.083)$ \\
\hline EXPORT & $0.481 * *(0.197)$ & $0.448 *(0.245)$ & $0.466^{* *}(0.195)$ & $0.473^{* *}(0.196)$ \\
\hline OUTS_FP & $0.490 * *(0.252)$ & & & \\
\hline OUTS_IP & & $2.526^{* * *}(0.510)$ & & \\
\hline OUTS_R\&D & & & $0.278(0.335)$ & \\
\hline OUTS_IT & & & & $0.020(0.212)$ \\
\hline \multicolumn{5}{|l|}{ Firm size } \\
\hline $\begin{array}{l}\text { Medium-sized } \\
\text { firms }\end{array}$ & $0.395 *(0.222)$ & $0.723^{* * *}(0.215)$ & $0.391 *(0.220)$ & $0.400 *(0.221)$ \\
\hline Large firms & $0.543^{* *}(0.237)$ & $0.693^{* * *}(0.256)$ & $0.519 * *(0.239)$ & $0.548^{* *}(0.236)$ \\
\hline \multicolumn{5}{|l|}{ Sector } \\
\hline $\begin{array}{c}\text { Manufacturing/ } \\
\text { services }\end{array}$ & $0.368^{*}(0.197)$ & $1.518^{* * *}(0.342)$ & $0.305(0.196)$ & $0.325 *(0.194)$ \\
\hline$N$ & 254 & 254 & 254 & 254 \\
\hline Pseudo $R^{2}$ & 0.078 & 0.150 & 0.069 & 0.067 \\
\hline Wald $\chi^{2}$ & $22.7^{* *}$ & $45.1^{* * *}$ & $20.1^{* *}$ & $20.1^{* *}$ \\
\hline
\end{tabular}

Note: Statistical significance at ${ }^{* * *} 1 \%,{ }^{*} 5 \%$, and ${ }^{\star} 10 \%$ test levels, respectively; heterosceda-sticity-robust standard errors (White-procedure).

\section{Summary and conclusions}

The aim of this article has been to analyze (i) the factors determining the firms' propensity to outsource various processes, and (ii) the impact of outsourcing on firms' innovation performance, as well as labor productivity. The new elements that this study adds to the existing literature are the following: the integral framework of analysis of the determining factors of several kinds of outsourcing, as well as their impact on innovation and productivity using the data sets; and the comparative setting for two countries, Greece and Switzerland, with fairly different levels of economic development. Also, in this article we examine four types of relocation to external providers, related to the production process of final products and intermediate products, as well as R\&D and ICT services, which are measured directly by having firms reporting whether they have externalized particular processes and functions in the period 2000-2005. 
Table 7 Probit estimates of the process innovation equations with outsourcing variables for Switzerland

\begin{tabular}{|c|c|c|c|c|}
\hline $\begin{array}{c}\text { Explanatory } \\
\text { variables }\end{array}$ & INNOPC & INNOPC & INNOPC & INNOPC \\
\hline $\mathrm{LnC/L}$ & $0.113^{* * *}(0.016)$ & $0.136^{* * *}(0.022)$ & $0.134 * * *(0.021)$ & $0.134 * * *(0.022)$ \\
\hline LnHQUAL & $0.058^{* * *}(0.026)$ & $0.070 * *(0.036)$ & $0.073^{* *}(0.036)$ & $0.075^{* * *}(0.036)$ \\
\hline D_INCREASE & $0.239 * * *(0.062)$ & $0.207 * * *(0.072)$ & $0.204 * * *(0.073)$ & $0.207 * * *(0.072)$ \\
\hline D_DECREASE & $0.272^{* * *}(0.068)$ & $0.251 * * *(0.081)$ & $0.257 * *(0.081)$ & $0.258^{* * *}(0.081)$ \\
\hline IPC & $0.093^{* * *}(0.025)$ & $0.088^{* * *}(0.031)$ & $0.089^{* * *}(0.031)$ & $0.089 * *(0.031)$ \\
\hline INPC & $0.062 * *(0.027)$ & $0.078 * *(0.032)$ & $0.079 * *(0.032)$ & $0.082 * *(0.032)$ \\
\hline EXPORT & $0.085(0.064)$ & $0.082(0.075)$ & $0.086(0.076)$ & $0.099(0.076)$ \\
\hline OUTS_FP & $0.773^{* * *}(0.258)$ & & & \\
\hline OUTS_IP & & $0.240 * *(0.107)$ & & \\
\hline OUTS_R\&D & & & $0.460 * * *(0.166)$ & \\
\hline OUTS_IT & & & & $0.222 * *(0.088)$ \\
\hline \multicolumn{5}{|l|}{ Firm size } \\
\hline Medium-sized firms & $0.104^{* * *}(0.033)$ & $0.067 *(0.037)$ & $0.074^{* *}(0.037)$ & $0.069 *(0.037)$ \\
\hline Large firms & $0.176^{* * *}(0.032)$ & $0.178^{* * *}(0.031)$ & $0.184^{* * *}(0.031)$ & $0.178^{* * *}(0.031)$ \\
\hline \multicolumn{5}{|l|}{ Sector } \\
\hline $\begin{array}{l}\text { High-tech } \\
\qquad \text { manufacturing }\end{array}$ & $-0.240(0.301)$ & $0.600 * * *(0.130)$ & $0.616^{* * *}(0.129)$ & $0.628^{* * *}(0.129)$ \\
\hline $\begin{array}{l}\text { Low-tech } \\
\qquad \text { manufacturing }\end{array}$ & $-0.050(0.209)$ & $0.521 * * *(0.121)$ & $0.529 * * *(0.120)$ & $0.524^{* * *}(0.120)$ \\
\hline $\begin{array}{l}\text { Knowledge-intensive } \\
\text { services }\end{array}$ & $0.396 * * *(0.119)$ & $0.386^{* * *}(0.135)$ & $0.381 * *(0.135)$ & $0.355^{* * *}(0.135)$ \\
\hline Traditional services & $0.235^{* * *}(0.108)$ & $0.175^{* * *}(0.118)$ & $0.169^{* * *}(0.117)$ & $0.157^{* * *}(0.118)$ \\
\hline$N$ & 1575 & 1575 & 1575 & 1575 \\
\hline Pseudo $R^{2}$ & 0.108 & 0.098 & 0.099 & 0.099 \\
\hline Wald $\chi^{2}$ & $339.0^{* * *}$ & $212.9^{* * *}$ & $214.8^{* * *}$ & $217.7^{* * *}$ \\
\hline
\end{tabular}

Note: Statistical significance at ${ }^{\star \star \star} 1 \%,{ }^{\star \star} 5 \%$, and ${ }^{\star} 10 \%$ test levels, respectively; heterosceda-sticity-robust standard errors (White-procedure).

In a first step, we specified based on existing theoretical and empirical literature an equation for the explanation of outsourcing at the firm level. This contained, besides controls for firm age, sector affiliation and the competition conditions, variables for the use of ICT, the use of certain forms of workplace organization, the degree of decentralization of decision-making, the existence of $\mathrm{R} \& \mathrm{D}$ activities, the educational level of the employees, the existence of export activities, the level of labor costs per employees, the demand perspectives, and firm size. We estimated this model for all four categories of outsourcing. 
Table 8 Probit estimates of the process innovation equations with outsourcing variables for Greece

\begin{tabular}{|c|c|c|c|c|}
\hline $\begin{array}{c}\text { Explanatory } \\
\text { variables }\end{array}$ & INNOPC & INNOPC & INNOPC & INNOPC \\
\hline LnASSET/L & $0.084(0.061)$ & $0.067(0.067)$ & $0.092(0.060)$ & $0.092(0.060)$ \\
\hline LnHQUAL & $0.036(0.087)$ & $-0.025(0.090)$ & $0.027(0.086)$ & $0.021(0.087)$ \\
\hline D_INCREASE & $-0.062(0.225)$ & $-0.032(0.263)$ & $-0.113(0.223)$ & $-0.086(0.222)$ \\
\hline D_DECREASE & $-0.318(0.328)$ & $1.099 *(0.570)$ & $-0.393(0.325)$ & $-0.351(0.324)$ \\
\hline IPC & $0.082(0.095)$ & $0.101(0.101)$ & $0.094(0.096)$ & $0.085(0.095)$ \\
\hline INPC & $0.007(0.082)$ & $-0.016(0.093)$ & $-0.021(0.083)$ & $-0.037(0.083)$ \\
\hline EXPORT & $0.310(0.198)$ & $0.268(0.223)$ & $0.291(0.197)$ & $0.267(0.196)$ \\
\hline OUTS_FP & $0.583 * *(0.256)$ & & & \\
\hline OUTS_IP & & $1.826^{* * *}(0.601)$ & & \\
\hline OUTS_R\&D & & & $0.219(0.343)$ & \\
\hline OUTS_IT & & & & $0.403 *(0.213)$ \\
\hline \multicolumn{5}{|l|}{ Firm size } \\
\hline $\begin{array}{l}\text { Medium-sized } \\
\text { firms }\end{array}$ & $0.657^{* * *}(0.231)$ & $0.906^{* * *}(0.263)$ & $0.656^{* * *}(0.229)$ & $0.646^{* * *}(0.228)$ \\
\hline Large firms & $0.869^{* * *}(0.246)$ & $0.979^{* * *}(0.252)$ & $0.849 * * *(0.247)$ & $0.850 * * *(0.244)$ \\
\hline \multicolumn{5}{|l|}{ Sector } \\
\hline $\begin{array}{c}\text { Manufacturing/ } \\
\text { services }\end{array}$ & $-0.082(0.199)$ & $0.701 * *(0.308)$ & $-0.147(0.196)$ & $-0.151(0.194)$ \\
\hline$N$ & 254 & 254 & 254 & 254 \\
\hline Pseudo $R^{2}$ & 0.108 & 0.138 & 0.093 & 0.104 \\
\hline Wald $\chi^{2}$ & $29.5^{* * *}$ & $39.6^{* * *}$ & $25.2^{* * *}$ & $30.9^{* * *}$ \\
\hline
\end{tabular}

Note: Statistical significance at ${ }^{* * *} 1 \%,{ }^{*} 5 \%$, and ${ }^{\star} 10 \%$ test levels, respectively; heterosceda-sticity-robust standard errors (White-procedure).

The results show remarkable differences between the different forms of outsourcing, as well as between the two countries. Intensive use of ICT is important for the outsourcing of ICT and R\&D in Switzerland but not in Greece. Organizational aspects, especially those related to the formal structure of workplace organization, are relevant for the Swiss firms but not for the Greek firms. These differences between the two countries can be explained, at least partly, by the fact that ICT and organization are considerably less important as factors determining productivity in Greece than in Switzerland, resulting in lower effectiveness and maturity of Greek firms in exploiting them in comparison with the Swiss ones. (Arvanitis and Loukis, 2009). The educational level of employees shows no effect in both countries. A common trait of both countries is that more innovative firms (R\&D) are stronger inclined to outsourcing activities than less innovative ones. Market conditions (demand, competition) are of minor importance. A further interesting result is that labor costs do 


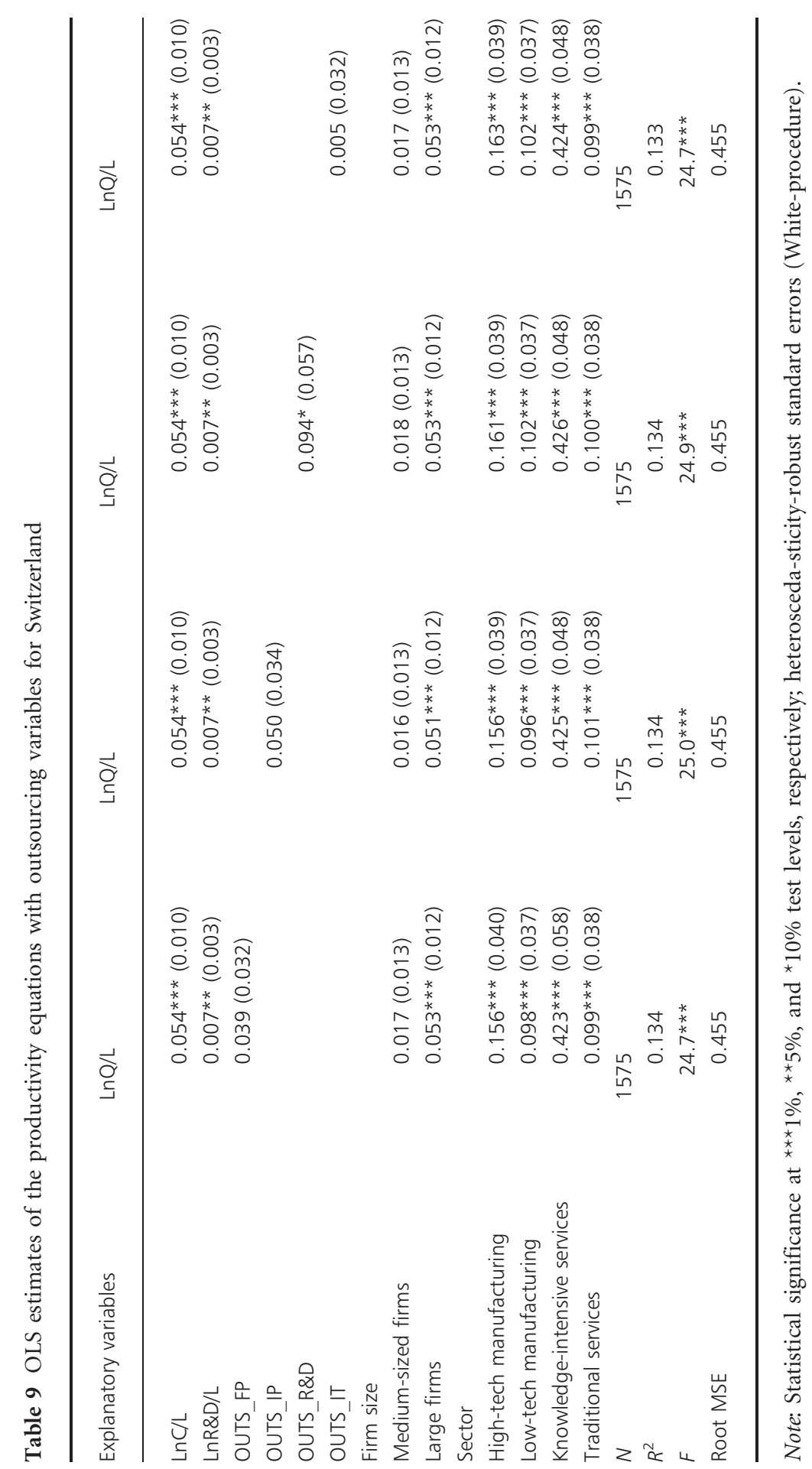


Table 10 OLS estimates of the productivity equations with outsourcing variables for Greece

\begin{tabular}{|c|c|c|c|c|}
\hline $\begin{array}{c}\text { Explanatory } \\
\text { variables }\end{array}$ & $\mathrm{LnQ} / \mathrm{L}$ & $\mathrm{LnQ} / \mathrm{L}$ & LnQ/L & LnQ/L \\
\hline LnASSET/L & $0.115^{* *}(0.042)$ & $0.120 * * *(0.040)$ & $0.120 * * *(0.040)$ & $0.119^{* * *}(0.040)$ \\
\hline LnR\&D/L & $0.024(0.020)$ & $0.026(0.021)$ & $0.029(0.021)$ & $0.028(0.022)$ \\
\hline OUTS_FP & $0.507 *(0.306)$ & & & \\
\hline OUTS_IP & & $-0.152(0.181)$ & & \\
\hline OUTS_R\&D & & & $-0.394(0.319)$ & \\
\hline OUTS_IT & & & & $-0.201(0.203)$ \\
\hline \multicolumn{5}{|l|}{ Firm size } \\
\hline $\begin{array}{l}\text { Medium-sized } \\
\text { firms }\end{array}$ & $0.255(0.177)$ & $0.248(0.161)$ & $0.264(0.162)$ & $0.261(0.156)$ \\
\hline Large firms & $0.045(0.176)$ & $0.107(0.168)$ & $0.153(0.161)$ & $0.126(0.167)$ \\
\hline \multicolumn{5}{|l|}{ Sector } \\
\hline $\begin{array}{l}\text { Manufacturing/ } \\
\text { services }\end{array}$ & $0.341(0.216)$ & $0.150(0.131)$ & $0.189(0.148)$ & $0.167(0.149)$ \\
\hline$N$ & 254 & 254 & 254 & 254 \\
\hline$R^{2}$ & 0.065 & 0.054 & 0.060 & 0.058 \\
\hline Wald $\chi^{2}$ & $14.9^{* *}$ & & & \\
\hline$F$ & & $2.7^{* *}$ & $3.1 * * *$ & $3.1 * * *$ \\
\hline Root MSE & 1.037 & 1.045 & 1.043 & 1.043 \\
\hline
\end{tabular}

Note: Statistical significance at ${ }^{* * *} 1 \%,{ }^{*} 5 \%$, and ${ }^{\star} 10 \%$ test levels, respectively; heterosceda-sticity-robust standard errors (White-procedure).

not appear to be a significant factor determining the likelihood of outsourcing. This means that labor costs saving is not a crucial incentive for outsourcing as part of economic literature supposes. Finally, we could not find a clear-cut firm size effect.

In a second step, we formulated an innovation equation that contained the outsourcing variables as right-hand variables. We found positive effects of outsourcing of the production of final and intermediate products on the propensity to product innovations for both countries, also of R\&D outsourcing for Switzerland. Further, we found positive effects for all four outsourcing activities for Switzerland and for three of them (exception: R\&D outsourcing) for Greece in the case of process innovation.

In a third step, we investigated the effects of outsourcing on labor productivity by inserting the outsourcing variables in a productivity equation. The results show a positive effect of R\&D outsourcing in the case of Switzerland and a positive effect of the outsourcing of the final products' production in the case of Greece. Thus, the productivity effects of outsourcing seem to be considerably weaker than the innovation effects. Outsourcing activities tend to enhance innovation, particularly process 
innovation, but only weakly directly productivity. For the Swiss firms, for which also a positive effect of $R \& D$ expenditure per employee on productivity was found, the productivity effects of outsourcing might be intermediated by new product and processes generated by R\&D investment.

Unfortunately, we could not distinguish in this study between outsourcing to domestic and foreign providers. Let us suppose that our results hold also for foreign outsourcing. In this case there are some interesting policy implications to be mentioned here. The first one is that high labor costs should not be necessarily the main driver of outsourcing. This is especially relevant for the high-wage country Switzerland. Second, even if efficiency gains due to outsourcing do not lead primarily to productivity increase, they seem to show themselves as drivers of the innovation performance of outsourcing firms.

\section{References}

Acemoglu, D., P. Aghion, R. Griffith and F. Zilibotti (2010), 'Vertical integration and technology: theory and evidence,' Journal of the European Economic Association, 8(5), 989-1033.

Abraham, K. G. and S. K. Taylor (1996), 'Firms' use of outside contractors: theory and evidence,' Journal of Labour Economics, 14(3), 394-424.

Abramovsky, L. and R. Griffith (2006), 'Outsourcing and offshoring of business services: How important is ICT?' Journal of the European Economic Association, 4(2/3), 594-601.

Abramovsky, L. and R. Griffith (2009), 'ICT, corporate restructuring and productivity,' IFS Working Paper WO9/10, London.

Alchian, A. A. and H. Demsetz (1972), 'Production, information costs, and economic organization,' American Economic Review, 62, 777-795.

Amiti, M. and S.-J. Wei (2006), 'Service offshoring and productivity: evidence from the United States,' NBER Working Paper No. 11926. Cambridge, MA.

Arvanitis, S. and H. Hollenstein (2007), 'Determinants of Swiss firms' R\&D activities at foreign locations: An empirical analysis based on firm-level data,' in G. R. G. Benito and H. R. Greve (eds), Progress in International Business Research, Vol. 1. Elsevier: Amsterdam, pp. 61-90.

Arvanitis, S. and H. Hollenstein (2011), 'How do different motives for R\&D investment in foreign locations affect domestic firm performance? An analysis based on Swiss panel micro data,' Industrial and Corporate Change, 20(2), 605-640.

Arvanitis, S. and E. Loukis (2009), 'Information and communication technologies, human capital, workplace organization and labour productivity in Greece and Switzerland: a comparative study based on firm-level data,' Information Economics and Policy, 21, 43-61.

Arvanitis, S. and E. Loukis (2011), 'Outsourcing and firm performance-a comparative study of Swiss and Greek firms,' KOF Working Paper Series No. 286, Zurich. http://www.kof.ethz. ch/de/publikationen/p/kof-working-papers/286. 
Barrios, S., S. Dimelis, H. Louri and E. Strobl (2004), 'Efficiency spillovers from foreign direct investment in the EU periphery: a comparative study of Greece, Ireland, and Spain,' Review of World Economics, 140(4), 688-705.

Bartel, A., S. Lach and N. Sicherman (2008), 'Outsourcing and technological innovations: a firm-level analysis,' IZA Discussion Paper No.3334, Bonn.

Bartel, A., S. Lach and N. Sicherman (2009), 'Outsourcing and technological change,' IZA Discussion Paper No.4678, Bonn.

Bresnahan, T. F., E. Brynjolfsson and L. M. Hitt (2002), 'Information technology, workplace organisation, and the demand for skilled labour: firm-level evidence,' Quarterly Journal of Economics, 112(1), 339-376.

Bustinza-Sanchez, O. F-, D. Arias-Aranda and L. Gutuerrez-Gutierezz (2010), 'Outsourcing, competitive capabilities and performance: An empirical study in service firms,' International Journal of Production Economics, 126(2), 276-288.

Canada Statistics (1999), Information and Communication Technologies and Electronic Commerce Survey. Canada Statistics: Ottawa.

Coad, A. (2011), 'Appropriate business strategy for leaders and laggards,' Industrial and Corporate Change, 20(4), 1049-1079.

Coase, R. H. (1937), 'The Nature of the Firm,' Economica, 4, 386-405.

Diaz-Mora, C. (2008), 'What factors determine the outsourcing intensity? A panel data approach for manufacturing industries,' Applied Economics, 40, 2509-2521.

Diaz-Mora, C. and A. Triguero (2007), 'Why do some firms contract out production? Evidence form firm-level panel data,' Estudios de Economia Espanol no. 232, FEDEA http://www.fedea.es/pub/eee232.pdf.

Debaere, P., H. Görg and H. Raff (2010), 'Greasing the wheels of international commerce: How services facilitate firms' international sourcing,' IZA Discussion Paper No. 4729, Bonn.

Dosi, G. (1988), 'Sources, procedures, and microeconomic effects of innovation,' Journal of Economic Literature, 26, 1120-1171.

Dimelis, S. and H. Louri (2002), 'foreign ownership and production efficiency: A quantile regression analysis,' Oxford Economic Papers, 54(3), 449-469.

EPOC (1997), New Forms of Work Organization. Can Europe Realize its Potential? Results of a Survey of Direct Employee Participation in Europe. European Foundation for the Improvement of Living and Working Conditions: Dublin.

Francois, J.-P., F. Favre and N. Greenan (1999), Organizational Changes in Industrial Firms and Computerization of Industrial Enterprises. OECD: Paris.

Girma, S. and H. Görg (2004), 'Outsourcing, foreign ownership, and productivity: Evidence from UK establishment-level data,' Review of International Economics, 12(5), 817-832.

Gooroochurn, N. and A. Hanley (2007), 'A tale of two literatures: Transition costs and property rights in innovation outsourcing,' Research Policy, 36, 1483-1495. 
Görg, H. and A. Hanley (2009), 'Services outsourcing and innovation: An empirical investigation,' IZA Discussion Paper No. 4404, Bonn.

Görg, H., A. Hanley and E. Strobl (2008), 'Productivity effects of international outsourcing: evidence from plant-level data,' Canadian Journal of Economics, 41(2), 670-688.

Görzig, B. and A. Stephan (2002), 'Outsourcing and firm-level performance,' DIW Discussion Paper No. 309. Berlin.

Greene, W. H. (2011), Econometric Analysis. Prentice-Hall: New York.

Grossman, S. and O. Hart (1986), 'The costs and benefits of ownership: A theory of vertical and lateral integration,' Journal of Political Economy, 94(4), 691-719.

Grossman, G. and E. Helpman (2002), 'Integration versus outsourcing in industry equilibrium,' Quarterly Journal of Economics, 117(1), 85-120.

Gusmano, L., L. M. Mancusi and A. Morrison (2010), 'Globalization of production and innovation: how outsourcing is reshaping an advanced manufacturing area,' Regional Studies, 44(3), 235-252.

Hamel, G. and C. K. Prahalad (1990), 'The core competence of the corporation,' Harvard Business Review, 68(3), 79-93.

Hempell, T. and T. Zwick (2008), 'New technology, work organization, and innovation,' Economics of Innovation and New Technology, 17(4), 331-354.

Heshmati, A. (2003), 'Productivity, growth, efficiency and outsourcing in manufacturing and service industries,' Journal of Economic Surveys, 17(1), 79-112.

Holl, A. (2008), 'Production subcontracting and location,' Regional Science and Urban Economics, 38, 299-309.

Jensen, M. C. and W. H. Meckling (1976), 'Theory of the firm: managerial behaviour, agency costs and ownership structure,' Journal of Financial Economics, 3, 305-360.

Kalleberg, A. L. (2001), 'Organizing flexibility: the flexible firm in a new century,' British Journal of Industrial Relations, 39, 479-504.

Kimura, E. (2002), 'Subcontracting and the performance of small and medium firms in Japan,' Small Business Economics, 18, 163-175.

Lewis, R. R. and D. E. M. Sappington (1991), 'Technological change and the boundaries of the firm,' American Economic Review, 81, 887-900.

Lileeva, A. and J. Van Biesebroeck (2008), 'Outsourcing when investments are specific and complementary,' NBER Working Paper No. 14477, Cambridge, MA.

Lindbeck, A. and D. J. Snower (2000), 'Multi-task learning and the reorganization of work: from Tayloristic to holistic organization,' Journal of Labor Economics, 18, 353-376.

Malone, T. W., J. Yates and R. I. Benjamin (1987), 'Electronic markets and electronic hierarchies,' Communications of ACM, 30(6), 484-497.

Mazzanti, M., S. Montresor and P. Pini (2009), 'What drives (or hampers) outsourcing? Evidence for a local production system in Emilia Romagna,' Industry and Innovation, 16(3), 331-365. 
McCann, F. (2009), 'Outsourcing and firm productivity in Irish manufacturing,' FIW Working Paper No. 21, FIW, Dublin.

Merino, F. and D. Rodriguez Rodriguez (2007), 'Business services outsourcing by manufacturing firms,' Industrial and Corporate Change, 16(6), 1147-1173.

Michie, J. and M. Sheehan (2005), 'Business strategy, human resources, labour market flexibility and competitive advantage,' International Journal of Human Resource Management, 16(3), 445-464.

Milgrom, P. and J. Roberts (1990), 'The economics of modern manufacturing,' American Economic Review, 80(3), 511-528.

Milgrom, P. and J. Roberts (1995), 'Complementarities and fit strategy, structure, and organizational change in manufacturing,' Journal of Accounting and Economics, 19(2-3), 179-208.

Mol, M. J. (2005), 'Does being R\&D intensive still discourage outsourcing? Evidence from Dutch manufacturing,' Research Policy, 34, 571-582.

Naghavi, A. and I. P. Ottaviano (2010), 'Outsourcing, complementary innovations, and growth,' Industrial and Corporate Change, 19(4), 1009-1035.

Novak, S. and S. D. Eppinger (2001), 'Sourcing by design: product complexity and the supply chain,' Management Science, 47(1), 189-204.

Olsen, K. B. (2006), 'Productivity impacts of offshoring and outsourcing: a review,' OECD STI Working Paper 2006/1, Paris.

Ohnemus, J. (2007), 'Does IT outsourcing increase firm success? An empirical assessment using firm-level data,' ZEW Discussion Paper No. 07-087, Mannheim.

Ohnemus, J. (2009), 'Productivity effects of business process outsourcing-a firm-level investigation based on panel data,' ZEW Discussion Paper No. 09-088, Mannheim.

Osterloh, J. (2004), Outsourcing of Secondary Service Domains-An Institutional and Cognitive Approach. Duncker and Humblot: Berlin (in German).

Quinn, J. B. and F. G. Hilmer (1994), 'Strategic outsourcing: leveraging knowledge capabilities,' Sloan Management Review, 35(4), 43-55.

Rivers, D. and Q. H. Vuong (1988), 'Limited information estimators and exogeneity tests for simultaneous probit models,' Journal of Econometrics, 39, 347-366.

Teece, D. J. (1986), 'Profiting from technological innovation,' Research Policy, 15, 285-305.

Teece, D. J., G. Pisano and A. Shuen (1997), 'Dynamic capabilities and strategic management,' Strategic Management Journal, 18, 509-533.

Tomiura, E. (2008), 'Foreign outsourcing and the product cycle: evidence from micro data,' Applied Economics Letters, 15, 1019-1022.

Vickery, G. and G. Wurzburg (1998), The Challenge of Measuring and Evaluating Organizational Change in Enterprises. OECD: Paris.

Williamson, O. E. (1975), Markets and Hierarchies: Analysis and Antitrust Implications. Free Press: New York. 
Williamson, O. E. (1985), The Economic Institutions of Capitalism: Firms, Markets, Relational

Contracting. Free Press: New York.

\section{Appendix}

Table A1 Composition of the data sets by industries and firm size classes

\begin{tabular}{|c|c|c|}
\hline & $\begin{array}{l}\text { Greece } \\
N(\%)\end{array}$ & $\begin{array}{l}\text { Switzerland } \\
N(\%)\end{array}$ \\
\hline \multicolumn{3}{|l|}{ Industry } \\
\hline Food, beverage & $25(9.2)$ & $77(4.5)$ \\
\hline Textiles & $(2.2)$ & $24(1.4)$ \\
\hline Clothing, leather & $7(2.6)$ & $6(0.3)$ \\
\hline Wood processing & $3(1.1)$ & $27(1.6)$ \\
\hline Paper & $3(1.1)$ & $24(1.4)$ \\
\hline Printing & $12(4.4)$ & $52(3.0)$ \\
\hline Chemicals & $12(4.4)$ & $66(3.8)$ \\
\hline Plastics, rubber & $6(2.2)$ & $38(2.2)$ \\
\hline Glass, stone, clay & $9(3.3)$ & $28(1.7)$ \\
\hline Metal & $4(1.5)$ & $24(1.4)$ \\
\hline Metal working & $7(2.6)$ & $106(6.2)$ \\
\hline Machinery & $1(0.4)$ & $165(9.7)$ \\
\hline Electrical machinery & $2(0.7)$ & $50(2.9)$ \\
\hline Electronics, instruments & $3(1.1)$ & $122(7.1)$ \\
\hline Vehicles & $2(0.7)$ & $20(1.1)$ \\
\hline Other manufacturing & $5(1.8)$ & $30(1.8)$ \\
\hline Energy & $3(1.1)$ & $33(1.9)$ \\
\hline Construction & $14(5.2)$ & $179(10.5)$ \\
\hline Wholesale trade & $52(19.2)$ & $142(8.3)$ \\
\hline Retail trade & $21(7.7)$ & $102(6.0)$ \\
\hline Hotels, catering & $27(10.0)$ & $56(3.3)$ \\
\hline Transport, Telecommunication & $15(5.2)$ & $91(5.3)$ \\
\hline Banks, insurances & $5(1.8)$ & $73(4.3)$ \\
\hline Real estate, leasing & $2(0.7)$ & $11(0.6)$ \\
\hline Business services & $16(5.9)$ & $151(8.8)$ \\
\hline Personal services & $10(3.7)$ & $11(0.6)$ \\
\hline \multicolumn{3}{|l|}{ Firm size } \\
\hline 20-49 employees & $88(32.5)$ & $474(27.7)$ \\
\hline 50-249 employees & $105(38.7)$ & $875(51.2)$ \\
\hline 250 employees and more & $78(28.8)$ & $361(21.1)$ \\
\hline Total & $281(100.0)$ & $1710(100.0)$ \\
\hline
\end{tabular}

